\title{
The role of benthic macrofauna in the trophic transfer of mercury in a low-diversity temperate coastal ecosystem (Puck Lagoon, southern Baltic Sea)
}

\author{
Agnieszka Jędruch (D) • Magdalena Bełdowska • \\ Marcelina Ziółkowska
}

Received: 5 October 2018 / Accepted: 21 January 2019/Published online: 7 February 2019

(C) The Author(s) 2019

\begin{abstract}
Mercury (Hg) is a global pollutant that affects human and ecosystem health. $\mathrm{Hg}$ is a serious threat especially for the marine environment, in which it undergoes bioaccumulation and biomagnification, reaching elevated concentrations in fish and other seafood. The research aimed at investigating the trophodynamics of $\mathrm{Hg}$ in the basal links of the marine food chain: benthic macrofauna and its main food sources (i.e. suspended and sediment organic matter, micro- and macrophytobenthos). The results showed that both the amount and the origin of organic matter affected the $\mathrm{Hg}$ level in particular trophic groups of macrozoobenthos. The intensive inflow of terrestrial material influenced the enrichment of suspended particles and microphytobenthos in $\mathrm{Hg}$, leading to increased $\mathrm{Hg}$ concentrations in filter-feeding macrofauna. The input of Hg-rich marine matter transported from the deeper parts of the Gulf of Gdańsk along with the near-bottom currents caused higher $\mathrm{Hg}$ levels in deposit feeders. The biomagnification factor (BMF) of $\mathrm{Hg}$ through benthic food web was dependent on environmental conditions occurring in the studied areas, in particular, factors favouring the growth and fecundity of macrofauna. Consequently, as a result of biodilution,
\end{abstract}

Electronic supplementary material The online version of this article (https://doi.org/10.1007/s10661-019-7257-y) contains supplementary material, which is available to authorized users.

A. Jędruch $(\bowtie) \cdot$ M. Bełdowska $\cdot$ M. Ziółkowska Institute of Oceanography, University of Gdańsk, Piłsudskiego 46, 81-378 Gdynia, Poland e-mail: agnieszka.jedruch@ug.edu.pl the trophic transfer of $\mathrm{Hg}$ was less effective in a more productive region, despite the elevated $\mathrm{Hg}$ concentrations in dietary components of the macrofauna and in the surrounding environment.

Keywords Mercury · Macrozoobenthos · Coastal food web - Trophic transfer - Biomagnification · Baltic Sea

\section{Introduction}

Mercury $(\mathrm{Hg})$ is considered to be one of the most dangerous global environmental pollutants and has been the subject of numerous scientific studies over many years. This is primarily related to the chemical and biological activity of $\mathrm{Hg}$, its high mobility, its rapid spread in the environment and its bioaccumulation and biomagnification abilities (Frörstner and Wittman 1981; Jackson 1998).

The Baltic, as a semi-enclosed sea with limited water exchange, surrounded by industrialised areas, has been the scene of uncontrolled discharge of contaminants containing $\mathrm{Hg}$ for decades. This has resulted in elevated concentrations of $\mathrm{Hg}$ the water and sediments and also in the organisms that inhabit the Baltic Sea (Wrembel 1993). Reductions in the Hg load entering the sea have only been observed since the 1990s (HELCOM 2010; Bełdowska 2016). In the case of the marine environment, this period is too short to show a significant reduction in the $\mathrm{Hg}$ concentration in its components (in other words, to get the ecosystem response to the introduced emission restrictions). This is shown by 
studies on $\mathrm{Hg}$ concentration in sediments (Bełdowska et al. 2013; Jędruch et al. 2015) or organisms that are associated with the marine bottom (Bełdowska et al. $2015,2016 b)$. These earlier studies also focused on the determination of $\mathrm{Hg}$ sources and loads entering the Baltic Sea. It is well known that $\mathrm{Hg}$ is mainly introduced into the Baltic via the inflow of river water and atmospheric deposition (HELCOM 2010; Bełdowska et al. 2015). Our results show that in the case of coastal areas, the $\mathrm{Hg}$ leaching from the land (i.e. due to coastal erosion and surface runoff from urbanised areas) plays an important role in the $\mathrm{Hg}$ load reaching the marine environment (Bełdowska et al. 2016a; Jędruch et al. 2017; Kwasigroch et al. 2018). Such sources are rarely considered when assessing the $\mathrm{Hg}$ budget in the marine environment, although in regions with a high inflow of terrestrial matter, a significant proportion of $\mathrm{Hg}$ accumulates in the coastal zone, especially in bottom sediments, from where it can enter the trophic chain by both phyto- and zoobenthic organisms (Bełdowska et al. 2015, 2016b; Jędruch et al. 2017, 2018a).

The evolutionary young age of the Baltic Sea in combination with the predominant brackish conditions results in naturally low species diversity, facilitating analyses of environmental response to anthropogenic pressures (Reusch et al. 2018). Baltic populations can serve as a test case on how trophodynamics of $\mathrm{Hg}$ may be influenced by global changes in environmental conditions observed in recent years (e.g. warming, acidification, oxygen depletion). Previous works shows that the physico-chemical parameters of water and its productivity play an important role in $\mathrm{Hg}$ bioaccumulation and tropic transfer, especially in low- and mediumtrophic level consumers (Bełdowska et al. 2016b; Chouvelon et al. 2018; Jędruch et al. 2018a). Additionally, the species-poor ecosystem of the Baltic Sea and its short postglacial history results in a relatively simple food web structure (Nordstöm et al. 2009; Sokołowski et al. 2012) and contributes to the increased trophic transfer of $\mathrm{Hg}$ (Lavoie et al. 2013).

Benthic organisms are an important element of the marine ecosystem - as a primary link in the trophic chain, they exist as a significant dietary component for many fish, seabirds, and humans. The main conditions that determine which fauna settle on the bottom are salinity, temperature, type of substrate (soft or hard bottom), the concentration of dissolved oxygen and the availability of food. The highest density and the most diverse composition of zoobenthic species are found in coastal waters. This is associated primarily with the varied topography, diverse habitat and higher productivity of shallow areas (Szymelfenig 2008). The type and abundance of zoobenthos are also influenced by the presence of underwater meadows-here, the higher density of phytobenthos creates favourable conditions for bottom-dwelling fauna (Jankowska et al. 2014; Sokołowski et al. 2015). Coastal ecosystem, are also characterised by functional richness of macrofauna, compared to open areas (Törnroos and Bonsdorff 2012). Even in the relatively poor in species Puck Lagoon, the benthic organisms have diversified functional properties (related to morphological, physiological, or behavioural aspects) and consequently varied feeding habits (e.g. consumption of suspended or sediment organic matter, plankton, microphytobenthos, live and dead animal tissues) (Jankowska et al. 2018). Thus, bottom fauna can accumulate $\mathrm{Hg}$ originating from many sources.

The transfer of $\mathrm{Hg}$ in the aquatic trophic chain has been the subject of many studies in recent years, with most of these studies focusing on freshwater bodies (e.g. Campbell et al. 2003; Wyn et al. 2009; Lavoie et al. 2010; Molina et al. 2010; Kidd et al. 2012). However, studies have shown that the process of bioaccumulation and biomagnification is more efficient in the marine environment than in the freshwater environment (Lavoie et al. 2013; Riyadi et al. 2015; Bełdowska and Falkowska 2016). A compilation of data on the transfer of $\mathrm{Hg}$ in the trophic chain in more than 200 aqueous systems indicates that many papers contain critical gaps in data and methodology (Lavoie et al. 2013). In many cases, the study was conducted only on a selected group of organisms (e.g. zooplankton, molluscs) or those of a high trophic status (e.g. predatory fish, birds). Neither the sources of $\mathrm{Hg}$ nor the concentration in the surrounding environment was considered. Furthermore, the research material was often collected only in one season (usually summer), thereby failing to take into account differences in the metabolic processes of organisms and the physico-chemical parameters of the environment, as well as changes in the amounts of autochthonous and allochthonous organic matter and Hg. Importantly, the role of the organisms from the lowest trophic levels in the trophodynamics of $\mathrm{Hg}$ in marine food chain is still not well recognised and requires further investigation (Chouvelon et al. 2018).

The purpose of this paper was, therefore, to determine the role of macrofauna in the transfer of $\mathrm{Hg}$ to the 
food chain at the sediment-primary production interface in a low-diversity temperate ecosystem, taking into account sources of $\mathrm{Hg}$ and the position of organisms in the trophic web. The authors decided to investigate the total $\mathrm{Hg}$ level in the most important elements of the benthic environment of the coastal area, which is associated with the fact that, as shown by previous studies, almost all $\mathrm{Hg}$ (94-99\%) accumulated in the macrozoobenthos occurs in bioavailable, labile forms (Jędruch et al. 2018b).

\section{Materials and methods}

\section{Study area}

The research was carried out at two sites in the Gulf of Gdańsk located in the southeastern part of the Baltic Sea (Fig. 1). The Gulf of Gdańsk area abounds in anthropogenic pollution sources, and most of these are located within the Tricity agglomeration situated on the southwestern coast (numerous facilities related to shipbuilding, energy and petrochemical industry and tourism). The main river entering this basin is the Vistula, the second largest river flowing into the Baltic. Stations in Osłonino and Chałupy were located in the coastal zone (depth $1 \mathrm{~m}$ ) of the Gulf of Gdańsk, in an area sheltered by the Hel Peninsula - the Puck Lagoon. For years, the Puck Lagoon has been exposed for an uncontrolled discharge of pollutants from the surrounding land. The accumulation of pollutants in the Puck Lagoon was favoured by shallow depth (average $3 \mathrm{~m}$ ), the shape of the sea bottom, and limited water exchange. On the other hand, these conditions are conducive to the growth of aquatic organisms - the Puck Lagoon ecosystem possesses the greatest biodiversity of any area within the Polish coastal zone of the Baltic (the species richness is about two times greater than in the open part of the Gulf of Gdańsk) (Sokołowski 2009). It is related to the fact that much of the bottom of the Puck Lagoon is covered by underwater meadows, including the most important species of seagrass-Zostera marina (Wesławski et al. 2013; Jankowska et al. 2014).

The station located on the western shore of the Puck Lagoon (Osłonino) was characterised by a large inflow of terrigenous matter associated with the inflow of few small rivers and the erosion of cliffs located in the vicinity. The station situated in the northern part of the Puck Lagoon (Chałupy) was slightly influenced by land - the main sources of organic matter were primary production and marine material transported from deeper parts of the sea (Bełdowska et al. 2016a; Jędruch et al. 2017).

\section{Sample collection}

Samples of benthic macrofauna and components of their diet were collected once a month from December 2011 to May 2013. The total number of sampling campaigns was 18 ; however, the biological material was collected 14 times at Osłonino station and 15 times at Chałupy station. During some winter months, samples of biota were not collected due to the presence of ice cover (at the Osłonino station: in February 2012 and from January 2013 to March 2013; at the Chałupy station: in February 2012 and from December 2012 to February 2013). Samples of macrofauna were collected using a manual Van Veen grab sampler with a grab area of $250 \mathrm{~cm}^{2}$, in three replicates. Collected surface sediments were then sieved through a $0.5-\mathrm{mm}$ mesh. The live biological material was placed in containers with sea water in situ and transported to the laboratory. All samples were kept aerated until analysis. Additionally, on each occasion, samples of other ecosystem components of the near-bottom zone were collected: subsurface sea water (in order to filter out the suspended particulate matter (SPM), phyto- and zooplankton, benthic macrophytes together with epiphytes, microalgal biofilm from rocks (epilithon), surface sediments (the upper $10 \mathrm{~cm}$ ), pore waters (using a rhizon in situ sampler) and suspended matter at the sediment-water interface (FLSM)). Sampling was carried out according to the commonly used methods described inter alia by Seeberg-Elverfeldt et al. (2005), Durai and Pandiyan (2011), Kelly and Zgrundo (2013) Bełdowska et al. (2015, 2016b), Bełdowska and Kobos (2016), Bełdowska and Mudrak-Cegiołka (2017) and Jędruch et al. (2017). In cases where they were observed in the area of research stations, small benthic fish were also collected (as potential consumers of macrozoobenthos). Additionally, the basic parameters (temperature, salinity and $\mathrm{pH}$ ) of near-bottom water were measured using the multi-parameter portable metre (ProfiLine Multi 3320, WTW, Germany). The redox potential was measured using an Eh-metre (Microscale Measurements, model MB II mV) (Graca et al. 2016). Immediately upon arrival at the laboratory, subsamples of the surface sediments were collected in order to determine their basic 


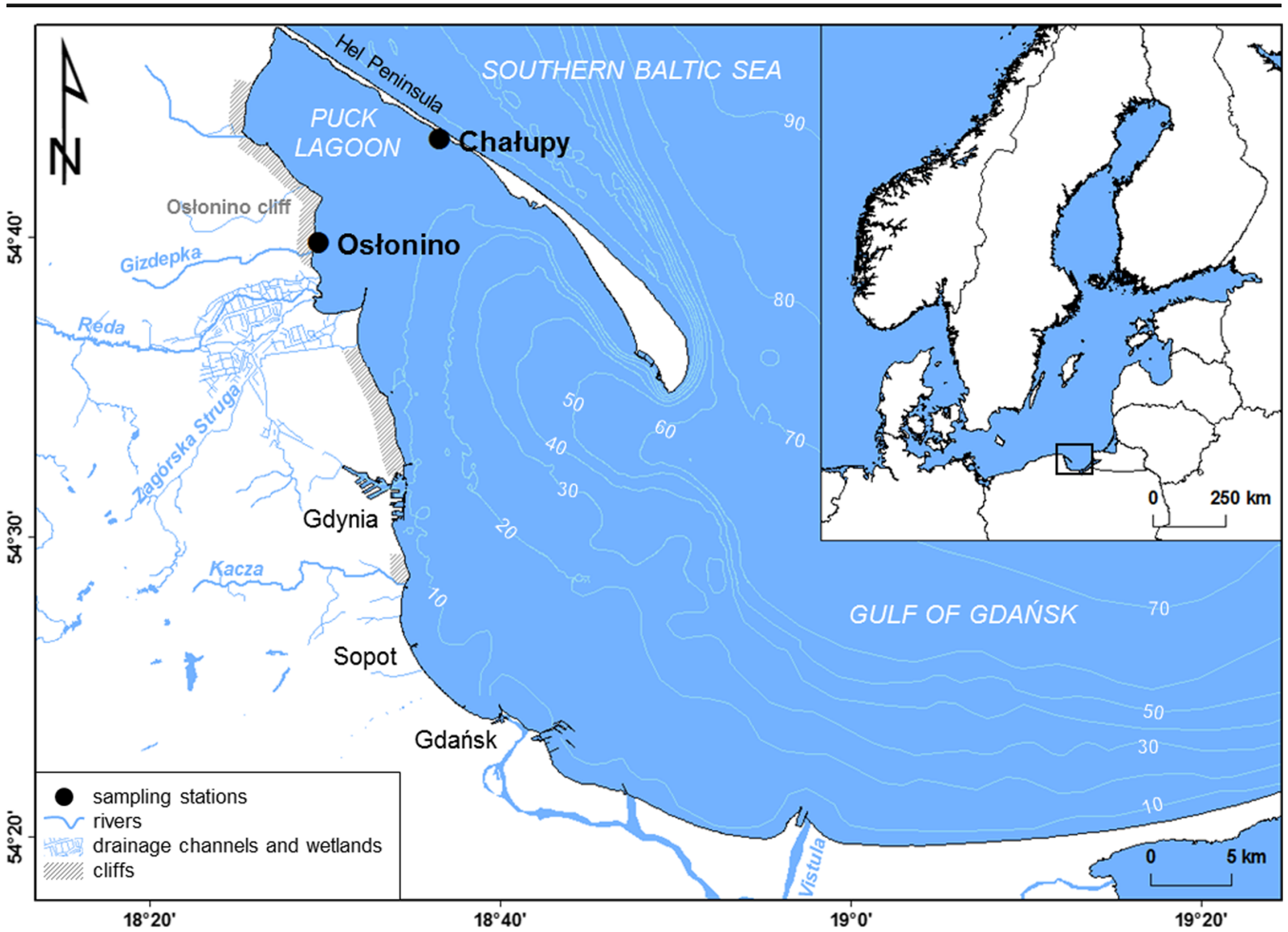

Fig. 1 Sampling stations in the Puck Lagoon (southern Baltic Sea)

properties: water content $(W)$, organic matter content estimated by loss on ignition (LOI) at $550{ }^{\circ} \mathrm{C}$ (Santisteban et al. 2004) and grain-size distribution in accordance with commonly used methods described in an earlier study by Jędruch et al. (2015).

\section{Biological analysis}

Laboratory analysis of macrozoobenthos samples included the determination of species composition, abundance and biomass. Taxonomic identification of organisms was carried out on the basis of observations of their morphological features and available taxonomic keys (Żmudziński 1990; Barnes 1994). Systematisation and nomenclature of macrofauna organisms were adopted in accordance with the World Register of Marine Species (WoRMS, www.marinespecies.org). To determine the biomass $\left(\mathrm{g} \mathrm{m}^{2}\right)$ of the organisms, they were freeze dried. The obtained results of abundance and biomass were converted to indicate $1 \mathrm{~m}^{2}$ of the bottom surface. The analysis of all macrozoobenthos samples was carried out in accordance with standards applicable in biological laboratory testing procedures used as part of an international monitoring of the Baltic Sea (HELCOM 1988).

For samples from the coastal zone, the following common community indices were used to estimate the structure of the macrozoobenthos - the dominance index $(D)$ and the frequency of occurrence $(C)$ (Tischler 1949; Trojan 1980). The dominance index of each taxon was calculated according to the formula:

$D=\frac{S_{\text {taxa }}}{S} \cdot 100$

where $S_{\text {taxa }}$ is the sum of the abundance (or biomass) of individuals belonging to a particular taxon in all examined samples and $S$ is the sum of the abundance (or biomass) of all individuals in all samples. Eudominant taxa are defined as $S \geq 10 \%$, taxa with $10>D \geq 5$ are dominant, taxa with $5>D \geq 2$ are subdominant, taxa with $2>D \geq 1$ are recedent and taxa with $D<1$ are classified as subrecedent (Trojan 1980). The frequency 
of occurrence, also referred to as a constancy index, revealed the dispersion of taxa in the investigated communities and was obtained from the following equation:

$C=\frac{n_{\text {taxa }}}{N} \cdot 100$

where $n_{\text {taxa }}$ is the number of samples containing a given taxon and $N$ is the total number of samples. Euconstant taxa are defined as having $C>75 \%$, taxa with $75 \% \geq$ $C>50 \%$ are constant, taxa with $50 \% \geq C>25 \%$ are referred to as accessory taxa and taxa with $C<25 \%$ belong to the group of accidental taxa (NapiórkowskaKrzebietke 2009; Marković et al. 2015).

Benthic macroalgae and vascular plants were identified to the lowest possible taxonomic level within 2 days of collection using the taxonomy key given by Braune and Guiry (2011). Nomenclature followed Algae Base (www.algaebase.org) and the European Register of Marine Species (ERMS, www.marbef.org/data/erms. php). Fish were identified to the species according to the atlas by Heessen et al. (2015).

\section{Determination of $\mathrm{Hg}$ concentration}

The preparation of macrozoobenthos samples for $\mathrm{Hg}$ analysis involved placing the taxonomically segregated biological material into single-use Eppendorf Safe-Lock Conical Tubes (volume 1.5 or $5.0 \mathrm{~mL}$ ), which have been previously rinsed with $4 \mathrm{M} \mathrm{HNO}_{3}$, dried at $60{ }^{\circ} \mathrm{C}$ and weighed. In the cases of bivalves (Cerastoderma glaucum, Limecola baltica, Mya arenaria), gastropods (Peringia sp., Radix labiata, Theodoxus fluviatilis) and crab (Rhithropanopeus harrisii), the soft body was separated from the shell or carapace using the stainless-steel scalpel blade (only soft body parts have been subjected to the further $\mathrm{Hg}$ analysis). The number of organisms placed in one tube was dependent on the individual mass of individuals of a given taxon (i.e. in the case of relatively large bivalves ranged from a few to a dozen or so, while in the case of small organisms such as gastropods, it accounted for tens of individuals). In particular tube, only the organisms of the same species, collected on the same station and in the same month (during the same sampling campaign), were placed. The same applies to the composite samples (prepared in the case when the biomass of organisms from a given species was small)_combining the sample included only the merging of material collected at the same time during the three replications. Prior to analysis, all samples (previously stored at a temperature of $-20{ }^{\circ} \mathrm{C}$ ) were freeze-dried (Alpha 1-4 LDplus, Martin Christ, Germany). Additionally, the samples of surface sediments were homogenised in a ball mill with agate vials (8000D Mixer/Mill, SPEX SamplePrep, USA). Total mercury concentrations $\left(\mathrm{Hg}_{\mathrm{TOT}}\right)$ in the collected material were determined using atomic absorption spectrometry (AAS) on the AMA-245 mercury analyser (Altec, Czech Republic). The analyses included the determination of $\mathrm{Hg}_{\text {Tот }}$ in each of the designated macrozoobenthos species, in one to five repetitions, depending on the mass of the organisms. $\mathrm{Hg}_{\text {тот }}$ concentrations were also analysed in primary producers (epilithon, epiphyton, macroalgae, and vascular plants) and benthic fish, as well as in SPM, FLSM and surface sediments. These analyses were performed by triplicate in the case of biological material and with five repetitions in the case of surface sediments. The quality control of the method included the analysis of certified reference materials (BCR 414-plankton, BCR 279-macroalgae Ulva lactuca, GBW 07314-offshore sediment). The method was characterised by high recovery (96$98 \%$ ), and the standard deviation did not exceed $5 \%$. The limit of detection (LOD) was $0.01 \mathrm{ng} \mathrm{g}^{-1}$.

The concentrations of $\mathrm{Hg}_{\mathrm{TOT}}$ measured in abiotic and biotic components were expressed in terms of dry weight (dw). In the case of surface sediments, concentrations of $\mathrm{Hg}_{\text {TОт }}$ were also presented as values normalised in relation to the percentage of fine-grained sediment fraction $\left(\mathrm{Hg}_{\mathrm{FSF}}\right)$ and the proportion of organic matter $\left(\mathrm{Hg}_{\mathrm{LOI}}\right)$ to compensate the differences in sediments parameters. The normalisation of $\mathrm{Hg}$ concentrations was performed in accordance with formulae presented in an earlier study by Jędruch et al. (2015):

$\mathrm{Hg}_{\mathrm{LOI}}=\frac{\mathrm{Hg}_{\mathrm{TOT}}}{\mathrm{LOI}\left(10^{-2}\right)}$

$\operatorname{Hg}_{\mathrm{FSF}}=\frac{\mathrm{Hg}_{\mathrm{TOT}}}{\operatorname{FSF}\left(10^{-2}\right)}$

where $\mathrm{Hg}_{\mathrm{LOI}}$ and $\mathrm{Hg}_{\mathrm{FSF}}$ are concentration of total $\mathrm{Hg}$ $\left(\mathrm{Hg}_{\mathrm{TOT}}\right)$ normalised to the content of organic matter (LOI) and fine sediment fraction (FSF) in the surface sediments, respectively. 
Determination of $\mathrm{Hg}$ bioaccumulation and biomagnification

To evaluate the ability of benthic organisms to accumulate $\mathrm{Hg}$ from surface sediment, the biotasediment accumulation factor (BSAF) was calculated following the formula suggested by Szefer et al. (1999):

$\mathrm{BSAF}=\frac{\mathrm{Hg}_{\text {biota }}}{\mathrm{Hg}_{\text {sediment }}}$

where $\mathrm{Hg}_{\text {biota }}$ and $\mathrm{Hg}_{\text {sediment }}$ are the concentrations of $\mathrm{Hg}$ in a given taxon and surface sediments, respectively.

In order to determine $\mathrm{Hg}$ accumulation in the trophic chain, the stable isotopic values of analysed components were used. The carbon and nitrogen isotopic compositions of suspended particulate matter (particulate organic matter, POM), sediments (sediment organic matter, SOM) and benthic organisms were expressed with the standard $\delta$ unit notation, given in parts per thousand (\%o), according to the following equation:

$\delta X=\left[\left(\frac{R_{\text {sample }}}{R_{\text {standard }}}\right)-1\right] \cdot 1000$

where $X$ is the stable isotope ratio of $\delta^{13} \mathrm{C}$ or $\delta^{15} \mathrm{~N}, R$ is the ratio of ${ }^{13} \mathrm{C} /{ }^{12} \mathrm{C}$ for carbon or ${ }^{15} \mathrm{~N} /{ }^{14} \mathrm{~N}$ for nitrogen for sample and for standard reference material (Pee Dee Belemnite (PDB) for $\delta^{13} \mathrm{C}$ and air for $\delta^{15} \mathrm{~N}$ ) (Khan et al. 2015). Data pertaining to the $\delta^{13} \mathrm{C}$ and $\delta^{15} \mathrm{~N}$ values in selected ecosystem components used in this study were taken from a simultaneous research project being conducted by the authors (Jędruch et al. 2017), as well as from literature (Hansson et al. 1997; Riera et al. 1999; Attrill et al. 2009; Nordstöm et al. 2009; Sokołowski 2009; Kolb et al. 2010; Riera 2010; Olsen et al. 2011; Prado et al. 2013; Karlson et al. 2015; Jankowska et al. 2016; Jankowska 2017; Jankowska et al. 2018). The majority of literature data were obtained from the Puck Lagoon and at similar time as this study (Table SI).

As nitrogen stable isotope $\left(\delta^{15} \mathrm{~N}\right)$ values provide an indication of the trophic position of an organism in the food web, the trophic level (TL) for each group of primary producers and consumers was estimated, using the following equation (Hobson and Welch 1992):

$\mathrm{TL}=\frac{\delta^{15} \mathrm{~N}_{\text {consumer }}-\delta^{15} \mathrm{~N}_{\text {baseline }}}{\Delta^{15} \mathrm{~N}}+2$

where TL is the trophic level of a given consumer, and $\delta^{15} \mathrm{~N}_{\text {consumer }}$ and $\delta^{15} \mathrm{~N}_{\text {baseline }}$ are $\delta^{15} \mathrm{~N}$ values of a consumer and the baseline organisms, respectively. The $\delta^{15} \mathrm{~N}_{\text {baseline for the study area (8.4) was }}$ previously calculated by Sokołowski et al. (2012) for all primary consumers in the study area. The $\Delta^{15} \mathrm{~N}$ is a trophic enrichment factor for $\delta^{15} \mathrm{~N}$ (3.4\%o) - the value by which the $\delta^{15} \mathrm{~N}$ increases in the subsequent levels of the trophic chain (Fry 2006; Sokołowski 2009; Lavoie et al. 2013).

To estimate the biomagnification potential of $\mathrm{Hg}$, also referred to as the trophic magnification slope (TMS), a theoretical model developed by Broman et al. (1992) and Rolff et al. (1993) for the trophic transfer of contaminants was applied:

$\mathrm{Hg}_{\text {compartment }}=\mathrm{Ae}^{\mathrm{B} \delta^{15} \mathrm{~N}}$

where $\mathrm{Hg}_{\text {compartment }}$ is the $\mathrm{Hg}_{\text {Tот }}$ concentration in sediments, particulate suspended matter and benthic organisms and $\mathrm{A}$ and $\mathrm{B}$ are the function parameters of $\mathrm{Hg}$ concentration and nitrogen isotopic value $\left(\delta^{15} \mathrm{~N}\right)$. The model constant $\mathrm{A}$ is a scaling factor that depends on $\mathrm{Hg}$ concentration at the base of the food chain (Rolff et al. 1993). In order to estimate the parameters $\mathrm{A}$ and $\mathrm{B}$, variables from Eq. 8 were converted using logarithmic transformation, resulting in linear regression:

$\ln \mathrm{Hg}_{\text {compartment }}=B \delta^{15} \mathrm{~N}+\ln \mathrm{A}$

The slope of this regression $(B)$ is the TMS (Broman et al. 1992), a parameter which is routinely used as an indicator of biomagnification potential of $\mathrm{Hg}$ in food webs around the world (i.e. Cai et al. 2007; Lavoie et al. 2010; Kim et al. 2012; Chouvelon et al. 2018). A positive slope (TMS $>0$ ) indicates $\mathrm{Hg}$ biomagnification in a food web, while a negative one $(\mathrm{TMS}<0$ ) indicates trophic diminution of $\mathrm{Hg}$ (Lavoie et al. 2013; Riyadi et al. 2015). Assuming that a change of stable nitrogen isotope of $3.4 \%$ represents one trophic level in the studied area (Sokołowski 2009; Sokołowski et al. 2015), the biomagnification factor (BMF), representing the increase of $\mathrm{Hg}$ concentration 
per trophic level, was calculated on the basis of antilogarithmic back-transformation (Hobson and Welch 1992):

$\mathrm{BMF}=\mathrm{e}^{3.4 \mathrm{~B}}$

\section{Processing results}

Statistical analysis of the obtained results was carried out using STATISTICA 12 software (StatSoft). The hypotheses were tested at statistical significance level of $p<0.05$. The analysed data were not characterised by the normal distribution (ShapiroWilk test, $p=0.00$ ). In order to determine the significance of differences, the non-parametric $U$ Mann-Whitney or Kruskal-Wallis' tests were used, as well as the multiple comparison post hoc Dunn's test. The relationships between the analysed variables were determined on the basis of the Spearman's coefficient. The outliers were determined by multiplying the interquartile range (IQR) by 1.5 , while the extreme values by multiplying IQR by 3 (Tukey 1997). The map of the study area with the distribution of sampling stations was created using ArcMap 10.4 software (ESRI) with the WGS1984 geographic coordinate system and UTM zone $33 \mathrm{~N}$ projection. The spatial data were provided courtesy of the GIS Centre, University of Gdańsk (www.ocean.ug.edu.pl/ oceju/CentrumGIS).

\section{Results}

\section{Characteristic of the benthic habitat}

The sampling stations located in the Puck Lagoon (Fig. 1) differed in terms of environmental conditions and type of bottom. The area of Osłonino was influenced by a strong inflow of suspended particulate matter (SPM), which was reflected by its high concentration in water at this station (median $36.1 \mathrm{mg} \mathrm{L}^{-1}$ ) (Table 1). In comparison, the concentration of SPM in Chałupy was three times lower (median $12.2 \mathrm{mg} \mathrm{L}^{-1}$ ). At both research stations, the surface sediments was sandy and medium-grained fraction of sands was dominant (grain diameter 250-500 $\mu \mathrm{m}$ ). However, the sediments at Osłonino stations contained more finest sediment fraction (FSF) with grain diameter below $63 \mu \mathrm{m}$ (median
$1.6 \%$ ) than sediments in Chałupy (median $0.3 \%$ ) (Table 1). It was similar in the case of the content of organic matter, estimated by loss of ignition (LOI), which share in Osłonino was higher (median 1.0\%) in comparison to Chałupy (median $0.3 \%$ ). The surface sediments collected at Osłonino and Chałupy were characterised by different oxygen conditions. Values of oxidation-reduction potential (Eh) measured in the area of Osłonino were lower (median $235.0 \mathrm{mV}$ ) than in Chałupy (median $299.0 \mathrm{mV}$ ). What is more, the Eh measured in Osłonino varied in a lesser range (71.0 $464.0 \mathrm{mV})$ in comparison to Chałupy $(-465.0$ $695.0 \mathrm{mV}$ ), during the study period. The other environmental parameters (salinity and $\mathrm{pH}$ ), measured in the near-bottom water, were slightly lower in the area of Osłonino (median S 6.4 PSU; median $\mathrm{pH} 7.8$ ) than in Chałupy (median $S 6.5$ PSU; median $\mathrm{pH}$ 8.0). However, at Osłonino station, these parameters periodically decreased and reached values as low as 4.3 PSU in the case of salinity, and 5.9 in the case of $\mathrm{pH}$, while in Chałupy the measured values varied in a narrower range (Table 1). The sampling station also differed in terms of bottom vegetation. In the area of Chałupy, the density of macrophytobenthos was higher in comparison to Osłonino station. Differences in species composition of benthic plants were also observed. In Chałupy, the rich occurrence of vascular plants, such as seagrass (Zostera marina) and brackish pondweed (Potamogeton spp. Zannichelia palustris), was observed. Among the macroalgae, the sea lettuce Enteromorpha sp. and charophyte green algae (Chara baltica) dominated at the Chałupy station. At Osłonino, vascular plants were less numerous and were represented mainly by Potamogeton spp. Macroalgae were in turn dominated by filamentous green algae Cladophora sp. and brown algae Pylaiella littoralis.

\section{Composition and structure of the macrozoobenthos}

A total of 20 taxa representing Bivalvia (Cerastoderma glaucum, Limecola balthica, Mya arenaria), Crustacea (Amphibalanus improvisus, Bathyporeia pilosa, Corophium sp., Gammarus sp., Idotea sp., Jaera sp., Rhithropanopeus harrisii, Lekanesphaera hookeri), Gastropoda (Peringia sp., Radix labiata, Theodoxus fluviatilis), Polychaeta (Hediste diversicolor, Marenzelleria sp., Streblospio shrubsolii), Oligochaeta, Nemertea and insect larvae were identified in samples of 
Table 1 Basic parameters of the near-bottom zone at stations located in the Puck Lagoon (southern Baltic Sea) in years 2011-2013

\begin{tabular}{|c|c|c|c|c|c|c|c|c|c|}
\hline \multirow[t]{2}{*}{ Station } & \multirow[t]{2}{*}{ Basic statistics } & \multirow{2}{*}{$\begin{array}{l}\text { SPM concentration } \\
\left(\mathrm{mg} \mathrm{L}^{-1}\right)\end{array}$} & \multicolumn{3}{|c|}{ Surface sediment properties } & \multicolumn{4}{|c|}{ Environmental parameters } \\
\hline & & & $W(\%)$ & LOI $(\%)$ & FSF $(\%)$ & $T\left({ }^{\circ} \mathrm{C}\right)$ & $S$ (PSU) & $\mathrm{pH}$ & $\mathrm{Eh}(\mathrm{mV})$ \\
\hline \multirow[t]{5}{*}{ Osłonino } & $N$ & 54 & 36 & 36 & 36 & 36 & 36 & 28 & 28 \\
\hline & Mean & 44.8 & 17.9 & 1.0 & 1.9 & 10.2 & 5.8 & 7.7 & 256.6 \\
\hline & Median & 36.1 & 17.3 & 1.0 & 1.6 & 9.5 & 6.4 & 7.8 & 235.0 \\
\hline & Min & 8.0 & 15.5 & 0.2 & 0.2 & -0.1 & 4.3 & 5.9 & 71.0 \\
\hline & Max & 140.6 & 22.1 & 2.0 & 6.5 & 24.0 & 7.1 & 8.1 & 464.0 \\
\hline \multirow[t]{5}{*}{ Chałupy } & $N$ & 51 & 36 & 36 & 36 & 36 & 36 & 30 & 30 \\
\hline & Mean & 33.6 & 16.1 & 0.7 & 0.4 & 10.2 & 6.4 & 8.0 & 271.7 \\
\hline & Median & 12.2 & 15.2 & 0.3 & 0.3 & 9.0 & 6.5 & 8.0 & 299.0 \\
\hline & Min & 5.6 & 12.1 & 0.2 & 0.1 & 0.3 & 6.0 & 7.0 & -435.0 \\
\hline & Max & 70.6 & 18.2 & 1.8 & 1.2 & 21.2 & 7.0 & 8.7 & 695.0 \\
\hline
\end{tabular}

$N$ number of analysed samples (including the number of repetitions: three in the case of suspended particulate matter, two in the case of sediment and environmental parameters), SPM suspended particulate matter, $W$ sediment wetness, LOI organic matter content, FSF fine sediment fraction content, $T$ temperature, $S$ salinity, $E h$ oxidation-reduction potential

macrozoobenthos collected in the Puck Lagoon (Table 2; Table SII). The number of macrozoobenthic taxa, as well as the species composition, depended on the location of the sampling station: 15 taxa have been identified in the area of Osłonino and 17 in the area of Chałupy. The occurrence of 12 macrozoobenthic taxa, C. glaucum, M. arenaria, Corophium sp., Gammarus sp., Idotea sp., R. harrisii, Peringia sp., H. diversicolor, Marenzelleria sp., Oligochaeta, Nemertea and insect larvae, was recorded at both research stations (Table SII).

In the area of the Osłonino station, eight taxa were classified as being euconstant or constant (frequency of occurrence higher than 50\%): L. balthica, Gammarus sp., Peringia sp., Oligochaeta, Corophium sp., $H$. diversicolor, insect larvae and $M$. arenaria (Table SII). The remaining seven species were counted as an accessory or accidental species. The dominant taxa in terms of abundance at the research area in Osłonino were Peringia sp. (38.0\%) and Corophium sp. (31.0\%). In terms of biomass, they were $H$. diversicolor (31.1\%) and Corophium sp. (30.4\%). At the station in Chałupy, 11 taxa of macrozoobenthos were euconstant or constant: H. diversicolor, C. glaucum, Gammarus sp., Peringia sp., Oligochaeta, L. hookeri, Idotea sp., T. fluviatilis, insect larvae, Corophium sp. and Nemertea. The remaining six species were counted as an accessory or accidental species. In terms of numbers in the area of the Chałupy station, Peringia sp. (50.1\%) and Oligochaeta $(21.1 \%)$ were the dominant taxa. In macrozoobenthic biomass, however, $H$. diversicolor (33.1\%) and Peringia sp. (17.5\%) were dominant (Table SII).

\section{Concentration of $\mathrm{Hg}$ in the diet components of the macrozoobenthos}

$\mathrm{Hg}_{\text {тот }}$ level in the elements of macrozoobenthos diet collected in the Puck Lagoon varied in a wide range depending on the type of food, and the differences between concentrations measured in particular types were statistically significant (Kruskal-Wallis test, $p=0.00$ ) (Table 3). $\mathrm{Hg}_{\mathrm{TOT}}$ in the investigated components increased in the following order-at Osłonino station: sediments < vascular plants < macroalgae $<$ epilithon $<$ SPM $<$ FLSM $<$ epiphyton $<$ phytoplankton $<$ zooplankton (Kruskal-Wallis test, $p=0.00)$ and at Chałupy station: sediments $<$ vascular plants $<$ macroalgae $<$ SPM $<$ epilithon $<$ phytoplankton < FLSM < epiphyton < zooplankton (Kruskal-Wallis test, $p=0.00$ ).

The lowest values were measured in the surface sediments in the case of both sampling stations. However, $\mathrm{Hg}_{\text {тот }}$ concentration in sediments collected in Osłonino was significantly higher (median $2.6 \mathrm{ng} \mathrm{g}^{-1}$ ) than in Chałupy (median $0.7 \mathrm{ng} \mathrm{g}^{-1}$ ) (U Mann-Whitney test, $p=0.00$ ) (Table 3). Relatively low levels of $\mathrm{Hg}_{\mathrm{TOT}}$ were measured in macrophytobenthos. In the case of vascular plants, $\mathrm{Hg}_{\mathrm{TO}}$ concentrations in samples from 
Table 2 Feeding mode, trophic group and trophic level of macrozoobenthos species in the coastal zone of the Puck Lagoon (southern Baltic Sea) in years 2011-2013. The data on the $\delta^{15} \mathrm{~N}$ used to calculate the tropic level can be found in Table SI and Fig. SI

\begin{tabular}{|c|c|c|}
\hline Food type & Feeding mode/habit & Trophic group \\
\hline
\end{tabular}

\begin{tabular}{|c|c|c|c|c|}
\hline \multicolumn{5}{|l|}{ Bivalvia } \\
\hline $\begin{array}{l}\text { Cerastoderma glaucum } \\
\text { (Bruguière, 1789) }\end{array}$ & POM, microalgae & Obligatory suspension feeder & Suspensivore & 2.09 \\
\hline $\begin{array}{l}\text { Limecola balthica (Linnaeus, } \\
1758 \text { ) }\end{array}$ & Microalgae, POM, SOM & $\begin{array}{l}\text { Facultative suspension/deposit } \\
\text { feeder }\end{array}$ & Suspensivore/detritivore & 2.32 \\
\hline $\begin{array}{l}\text { Mya arenaria (Linnaeus, } \\
1758 \text { ) }\end{array}$ & POM, microalgae & Obligatory suspension feeder & Suspensivore & 2.35 \\
\hline \multicolumn{5}{|l|}{ Crustacea } \\
\hline $\begin{array}{l}\text { Amphibalanus improvisus } \\
\text { (Darwin, 1854) }\end{array}$ & Microalgae, POM & Suspension feeder & Suspensivore & 2.00 \\
\hline $\begin{array}{l}\text { Bathyporeia pilosa } \\
\text { (Lindström, 1855) }\end{array}$ & Microalgae, SOM & Facultative grazer/deposit feeder & Grazer & 2.18 \\
\hline $\begin{array}{l}\text { Corophium sp. (Latreille, } \\
\text { 1806) }\end{array}$ & SOM, microalgae & $\begin{array}{l}\text { Facultative deposit/suspension } \\
\text { feeder/grazer }\end{array}$ & Suspensivore/detritivore & 1.94 \\
\hline $\begin{array}{l}\text { Gammarus sp. (Fabricius, } \\
\text { 1775) }\end{array}$ & $\begin{array}{l}\text { SOM, microalgae, live and dead } \\
\text { animal tissue }\end{array}$ & Deposit feeder & Omnivore & 2.12 \\
\hline Idotea sp. (Fabricius, 1798) & Microalgae, macroalgae & Herbivore & Grazer & 2.32 \\
\hline Jaera sp. (Leach, 1814) & Microalgae, SOM & $\begin{array}{l}\text { Herbivore/facultative deposit } \\
\text { feeder }\end{array}$ & Grazer & 1.78 \\
\hline $\begin{array}{l}\text { Rhithropanopeus harrisii } \\
\text { (Gould, 1841) }\end{array}$ & $\begin{array}{l}\text { SOM, microalgae, live and dead } \\
\text { animal tissue }\end{array}$ & Deposit feeder & Omnivore & 2.32 \\
\hline $\begin{array}{l}\text { Lekanesphaera hookeri } \\
\quad \text { (Leach, 1814) }\end{array}$ & Microalgae, macroalgae & Herbivore & Grazer & 2.53 \\
\hline \multicolumn{5}{|l|}{ Gastropoda } \\
\hline Peringia sp. (Hartmann, 1821) & Microalgae, SOM & $\begin{array}{l}\text { Herbivore/facultative deposit } \\
\text { feeder }\end{array}$ & Grazer & 2.15 \\
\hline $\begin{array}{l}\text { Radix labiata (Rossmässler, } \\
\text { 1835) }\end{array}$ & Microalgae, macroalgae, SOM & $\begin{array}{l}\text { Herbivore/facultative deposit } \\
\text { feeder }\end{array}$ & Grazer & 1.91 \\
\hline $\begin{array}{l}\text { Theodoxus fluviatilis } \\
\text { (Linnaeus, 1758) }\end{array}$ & Microalgae, macroalgae, SOM & $\begin{array}{l}\text { Herbivore/facultative deposit } \\
\text { feeder }\end{array}$ & Grazer & 1.79 \\
\hline \multicolumn{5}{|l|}{ Polychaeta } \\
\hline $\begin{array}{l}\text { Hediste diversicolor (Müller, } \\
\text { 1776) }\end{array}$ & $\begin{array}{l}\text { SOM, microalgae, live and dead } \\
\text { animal tissue }\end{array}$ & $\begin{array}{l}\text { Facultative deposit } \\
\text { feeder/predator/scavenger }\end{array}$ & Omnivore & 2.56 \\
\hline $\begin{array}{l}\text { Marenzelleria sp. (Mesnil, } \\
\text { 1896) }\end{array}$ & $\begin{array}{l}\text { Microalgae, SOM, live and dead } \\
\text { animal tissue }\end{array}$ & $\begin{array}{l}\text { Facultative deposit } \\
\text { feeder/predator/scavenger }\end{array}$ & Omnivore & 2.71 \\
\hline $\begin{array}{l}\text { Streblospio shrubsolii } \\
\text { (Buchanan, 1890) }\end{array}$ & SOM, microalgae & $\begin{array}{l}\text { Facultative deposit/suspension } \\
\text { feeder }\end{array}$ & Suspensivore/detritivore & nd \\
\hline Oligochaeta & Bacteria, SOM & Deposit feeder & Detritivore & 2.09 \\
\hline Nemertea & Live and dead animal tissue & Predator/scavenger & Omnivore & 2.21 \\
\hline Insect larvae & $\begin{array}{l}\text { Microalgae, live and dead animal } \\
\text { tissue }\end{array}$ & $\begin{array}{l}\text { Facultative deposit } \\
\text { feeder/predator/scavenger }\end{array}$ & Omnivore & 2.85 \\
\hline
\end{tabular}

nd no data

Osłonino (median $8.0 \mathrm{ng} \mathrm{g}^{-1}$ ) were similar to the values in Chałupy (median $7.9 \mathrm{ng} \mathrm{g}^{-1}$ ) ( $U$ Mann-Whitney test, $p=0.79$ ), as in the case of macroalgae, in which $\mathrm{Hg}_{\mathrm{TO}}$ concentrations measured in Osłonino (median $17.5 \mathrm{ng} \mathrm{g}^{-1}$ ) were only slightly higher than those in Chałupy (median $16.1 \mathrm{ng} \mathrm{g}^{-1}$ ) ( $U$ Mann-Whitney test, $p=0.14$ ). In microphytobenthos, $\mathrm{Hg}_{\mathrm{TO}}$ concentrations were higher than those measured in macrophytes, especially in the case of epiphytes, in which measured values were over three times greater, both in Osłonino (median $66.9 \mathrm{ng} \mathrm{g}^{-1}$ ) and Chałupy (59.5 $\mathrm{ng} \mathrm{g}^{-1}$ ). Similar to macrophytobenthos, $\mathrm{Hg}_{\mathrm{TO}}$ concentrations in benthic microflora did not differ statistically significant at the sampling stations both in epilithon ( $U$ Mann-Whitney 


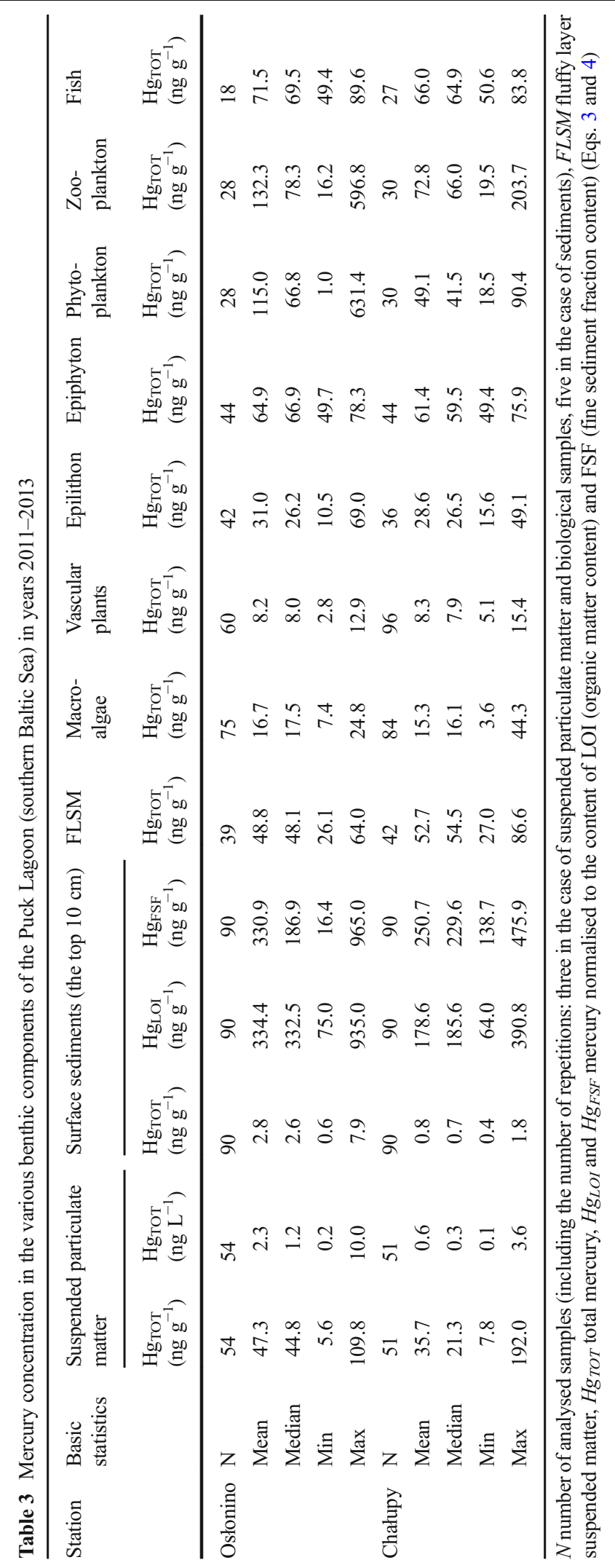


test, $p=0.73$ ) and epiphyton ( $U$ Mann-Whitney test, $p=0.23$ ). Significant differences between Osłonino and Chałupy stations were noted in the case of an important food source, the suspended particulate matter ( $U$ Mann-Whitney test, $p=0.03$ ). $\mathrm{Hg}_{\text {TOT }}$ concentrations in SPM at Osłonino (median $44.8 \mathrm{ng} \mathrm{g}^{-1}$ ) were two times higher than values in Chałupy (median $21.3 \mathrm{ng} \mathrm{g}^{-1}$ ). Higher $\mathrm{Hg}_{\text {Tот }}$ levels in Osłonino (median $66.8 \mathrm{ng} \mathrm{g}^{-1}$ ) in comparison to Chałupy (median $41.5 \mathrm{ng} \mathrm{g}^{-1}$ ) were also measured in other significant component of macrofauna diet, which is phytoplankton ( $U$ Mann-Whitney test, $p=0.04$ ). The highest $\mathrm{Hg}_{\text {TOT }}$ level was noted in zooplankton, both in the case of the station in Osłonino (median $78.3 \mathrm{ng} \mathrm{g}^{-1}$ ) and in Chałupy (median $64.9 \mathrm{ng} \mathrm{g}^{-1}$ ) (Table 3).

\section{Concentration of $\mathrm{Hg}$ in the macrozoobenthos}

$\mathrm{Hg}_{\text {тот }}$ concentrations in the macrozoobenthos of the Puck Lagoon ranged from $7.4 \mathrm{ng} \mathrm{g}^{-1}$ to $521.2 \mathrm{ng} \mathrm{g}^{-1}$, wherein the values measured in individual species differed statistically (KruskalWallis test, $p=0.00$ ) (Table 4 ). The highest median concentration of $\mathrm{Hg}_{\text {тот }}$ was measured in $B$. pilosa (471.3 $\mathrm{ng} \mathrm{g}^{-1}$ ) collected in Osłonino, while the lowest were noted in A. improvisus (4.1 $\mathrm{ng} \mathrm{g}^{-1}$ ) collected in Chałupy. However, both taxa were classified as accidental, which means they had low frequency of occurrence in the studied area (Table SII).

Considering only the $\mathrm{Hg}_{\text {тот }}$ level in nine constant or euconstant species (after rejection of accessory and accidental taxa) common to both research stations (C. glaucum, M. arenaria, Corophium sp., Gammarus sp., Idotea sp., Peringia sp., H. diversicolor, Oligochaeta and insect larvae), the differences between concentrations measured in Chałupy and Osłonino were not statistically significant ( $U$ Mann-Whitney test, $p=0.50$ ). However, the distribution of $\mathrm{Hg}_{\mathrm{TO}}$ concentrations in individual species at these stations was diverse (Fig. 2). $\mathrm{Hg}_{\text {TOT }}$ in the investigated organisms increased in the following order - at Osłonino station: M. arenaria < Idotea $\mathrm{sp.} \mathrm{<}$ Gammarus sp. $<H$. diversicolor $<$ Oligochaeta $<$ Corophium sp. < insect larvae < Peringia sp. < C. glaucum (Kruskal-Wallis test, $p=0.01$ ) and at Chałupy station: insect larvae $<H$. diversicolor $<$ Oligochaeta $<$ C. glaucum $<$ Gammarus sp. $<$ Corophium sp. $<$ Idotea sp. $<$ Peringia sp. $<$ M. arenaria (KruskalWallis test, $p=0.00$ ) (Fig. 2; Table 4). On the basis of inter-species variation of $\mathrm{Hg}_{\mathrm{TOT}}$ level (multiple comparison of ranks), the three groups of organisms were separated. In the area of Osłonino, the first group with the highest concentrations of $\mathrm{Hg}_{\text {Tот }}$ (consisted of two taxa: C. glaucum (median $74.7 \mathrm{ng} \mathrm{g}^{-1}$ ) and Peringia sp. (median $54.3 \mathrm{ng} \mathrm{g}^{-1}$ ), the second group with moderate $\mathrm{Hg}_{\text {TОт }}$ level was represented by three taxa: insect larvae (median $50.3 \mathrm{ng} \mathrm{g}^{-1}$ ), Corophium sp. (median $42.2 \mathrm{ng} \mathrm{g}^{-1}$ ) and Idotea sp. (median $26.7 \mathrm{ng} \mathrm{g}^{-1}$ ), while the lowest $\mathrm{Hg}_{\text {TОт }}$ concentrations were measured in third group consisting of four taxa: Oligochaeta (median $36.3 \mathrm{ng} \mathrm{g}^{-1}$ ), Gammarus sp. (median $28.6 \mathrm{ng} \mathrm{g}^{-1}$ ), H. diversicolor (median $28.9 \mathrm{ng} \mathrm{g}^{-1}$ ) and $M$. arenaria (median $14.0 \mathrm{ng} \mathrm{g}^{-1}$ ). The significant differences in the $\mathrm{Hg}_{\text {TOT }}$ concentrations were observed between first and third group (Dunn's test, $p=0.00$ ). In the case of the Chałupy station, the first group of constant taxa with the highest $\mathrm{Hg}_{\text {тот }}$ was $M$. arenaria (median $65.7 \mathrm{ng} \mathrm{g}^{-1}$ ) and Peringia sp. (median $59.8 \mathrm{ng} \mathrm{g}^{-1}$ ), the second group was consisting of five taxa: Idotea $\mathrm{sp}$. (median $37.1 \mathrm{ng} \mathrm{g}^{-1}$ ), Corophium sp. (median $34.9 \mathrm{ng} \mathrm{g}^{-1}$ ), Gammarus sp. (median $31.6 \mathrm{ng} \mathrm{g}^{-1}$ ), C. glaucum (median $22.5 \mathrm{ng} \mathrm{g}^{-1}$ ) and insect larvae (median $17.9 \mathrm{ng} \mathrm{g}^{-1}$ ), while the third group was represented by Oligochaeta (median $21.8 \mathrm{ng} \mathrm{g}^{-1}$ ) and H. diversicolor (median $21.6 \mathrm{ng} \mathrm{g}^{-1}$ ). The significant differences in the $\mathrm{Hg}_{\text {тот }}$ concentrations were observed between every pair of groups: between first and second (Dunn's test, $p=0.02$ ), first and third $(p=0.00)$ and second and third $(p=0.04)$.

Taking into account the feeding mode of the macrofauna (Table 2), the collected organisms were assigned to three trophic groups: suspensivores and/or detritivores, grazers and omnivores. Concentration of $\mathrm{Hg}_{\text {тот }}$ in these groups increased in the following order-at Osłonino station: omnivores (37.7 $\left.\mathrm{ng} \mathrm{g}^{-1}\right)<$ suspensivores and/or detritivores (38.7 $\left.\mathrm{ng} \mathrm{g}^{-1}\right)<$ grazers $\left(50.0 \mathrm{ng} \mathrm{g}^{-1}\right.$ ) (KruskalWallis test, $p=0.27$ ) and at Chałupy suspensivores and/or detritivores (24.3 $\left.\mathrm{ng} \mathrm{g}^{-1}\right)<$ omnivores (28.9 $\left.\mathrm{ng} \mathrm{g}^{-1}\right)<\operatorname{grazers}\left(51.2 \mathrm{ng} \mathrm{g}^{-1}\right.$ ) (KruskalWallis test, $p=0.01$ ) (Fig. 3). The significant differences in the $\mathrm{Hg}_{\mathrm{TOT}}$ concentrations measured in the different trophic groups of macrozoobenthos were noted only at Chałupy station: between suspensivores and/or detritivores and grazers (Dunn's test, $p=0.02$ ) and between grazers and omnivores $(p=0.00)$. 


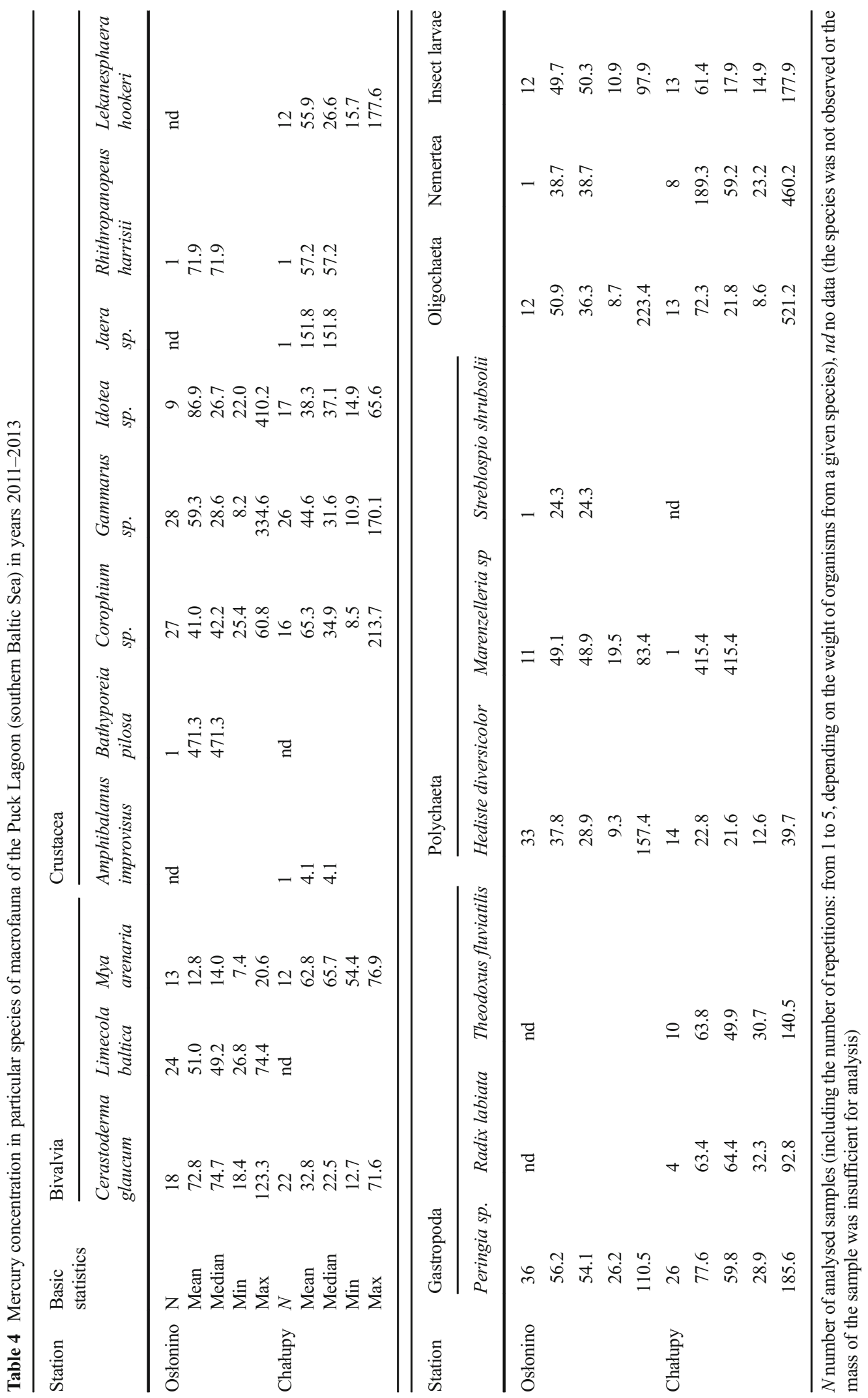


Fig. 2 Total mercury $\left(\mathrm{Hg}_{\mathrm{TOT}}\right)$ concentration in macrozoobenthos of the coastal zone of the Puck Lagoon (southern Baltic Sea) in years 2011-2013 (species common to both stations, excluding accidental taxa)

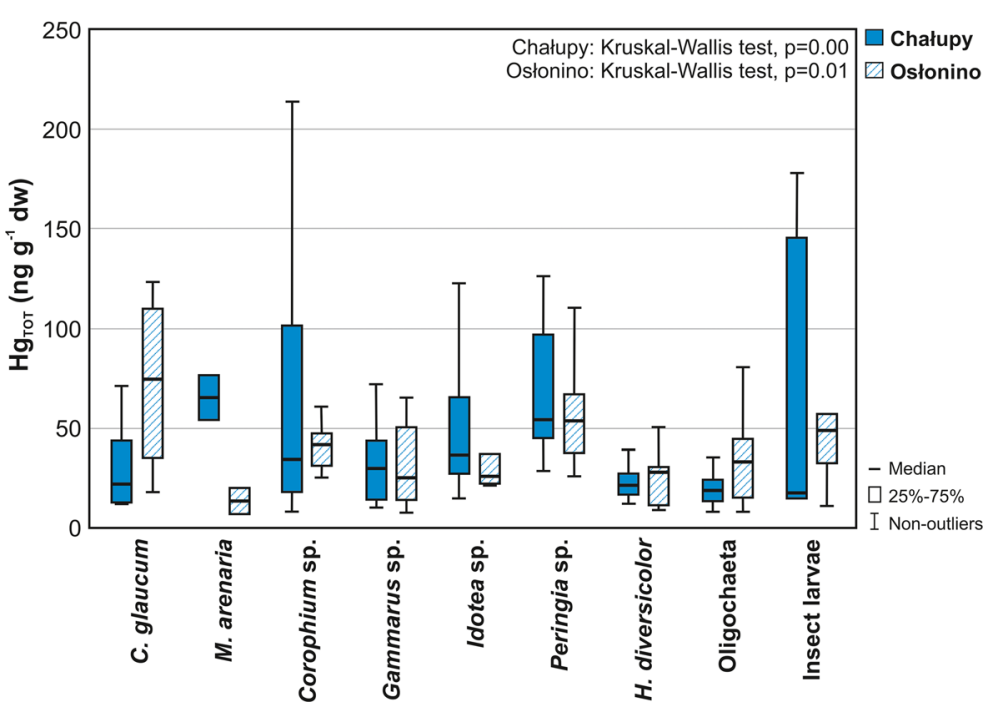

The inner part of a semi-enclosed gulf-Ostonino

The Osłonino station was located in the direct impact zone of land-based sources. The increased surface runoff was related to the proximity of river estuaries and coastal abrasion (Fig. 1), and the limited water dynamics were conducive to the accumulation of organic matter (Bełdowska et al. 2016a; Jędruch et al. 2017; Kwasigroch et al. 2018). This resulted in the high concentration of SPM in the area of Osłonino (Table 1) and its isotopic composition, indicating terrigenous origin (median $\delta^{13} \mathrm{C}-24.3 \%$; median $\delta^{15} \mathrm{~N} 4.2 \%$; median $\mathrm{C}_{\mathrm{ORG}} / \mathrm{N}_{\text {TOT }}$ 9.7) (Jędruch et al. 2017) (Table SI). Low water dynamics in the area of the Osłonino station allowed sediments of a smaller size to be deposited there more than at the Chałupy station (Table 1). The availability of food in the form of particulate organic matter
Fig. 3 Total mercury $\left(\mathrm{Hg}_{\mathrm{TOT}}\right)$ concentration in the main trophic groups of macrozoobenthos of the coastal zone of the Puck Lagoon (southern Baltic Sea) in years 2011-2013

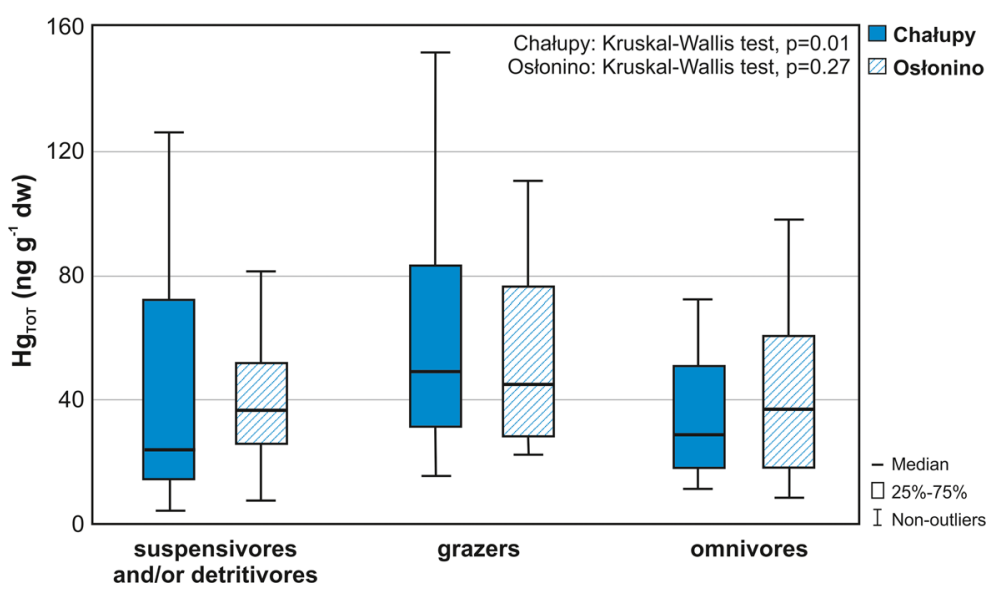


(POM) and sediment organic matter (SOM) has contributed to the development of suspension/deposit feeders such as Corophium sp. (crustacean), C. glaucum and L. balthica (clams) and Oligochaeta (Table 2), whose share in the zoobenthos biomass in the area of Osłonino was greater than in Chałupy (Table SII).

Increased surface runoff and accumulation of matter in the coastal zone in the vicinity of the station also influenced higher $\mathrm{Hg}_{\text {TOт }}$ concentrations in SPM and surface sediments, as well as in the analysed biotic components, phytobenthos, epilithon, epiphyton and plankton (Table 3), compared to the Chałupy station situated away from land sources. In nine macrozoobenthic taxa, common to both research stations (Table SII), higher $\mathrm{Hg}_{\text {ТОт }}$ concentrations were observed in the area of Osłonino than Chałupy in five taxa: $C$. glaucum, insect larvae, Oligochaeta, $H$. diversicolor and Corophium sp. (Fig. 2). The biggest difference was observed in the suspension feeder C. glaucum, in which the concentration of $\mathrm{Hg}_{\text {TOт }}$ in Osłonino (median $74.7 \mathrm{ng} \mathrm{g}^{-1}$ ) was more than three times higher than in Chałupy (median $22.5 \mathrm{ng} \mathrm{g}^{-1}$ ) (Fig. 2; Table 4). The diet of this species consists of microalgae (including phytoplankton, microphytobenthos, and epiphytes) and SPM (Rossi et al. 2004; Olenin and Daunys 2005). High concentrations of $\mathrm{Hg}_{\mathrm{TOT}}$ in C. glaucum in Osłonino were connected with elevated metal concentrations in its food sources. This is confirmed by correlation of $\mathrm{Hg}_{\mathrm{TOT}}$ concentration in $C$. glaucum and in phytoplankton $(R=0.67)$ and correlation of $\mathrm{Hg}_{\mathrm{TOT}}$ level in C. glaucum and SPM $(R=0.43)$ (Table SIII). In the case of phytoplankton, the $\mathrm{Hg}_{\mathrm{TO}}$ concentration at the Osłonino station was about $60 \%$ higher than at the Chałupy station, and the concentration of $\mathrm{Hg}_{\mathrm{TO}}$ in SPM in Osłonino was three times higher than in Chałupy (Table 3). A significant difference was also observed in the case of omnivorous insect larvae, for which the concentration of $\mathrm{Hg}_{\mathrm{TOT}}$ in Osłonino (median $49.6 \mathrm{ng} \mathrm{g}^{-1}$ ) was about 2.5 times higher than in Chałupy (median $17.9 \mathrm{ng} \mathrm{g}^{-1}$ ) (Table 4). Due to the fact that insect larvae have a very diverse diet, including microalgae, live and dead animal tissue and sometimes also detritus (Table 2) (Sanseverino and Nessimian 2001; Pekcan-Hekim et al. 2006), no statistically significant correlation was observed between the $\mathrm{Hg}_{\text {TOT }}$ concentration in these organisms and the $\mathrm{Hg}_{\mathrm{TOT}}$ concentration in any of their dietary components. Nevertheless, the elevated $\mathrm{Hg}_{\mathrm{TOT}}$ concentration in insect larvae in Osłonino can be attributed to higher $\mathrm{Hg}_{\text {TOT }}$ concentrations in their potential sources of food there than at Chalupy (Table 3). Other taxa for which the concentration of $\mathrm{Hg}_{\mathrm{TO}}$ was higher in the area of Osłonino were Oligochaetes, Corophium sp. and $H$. diversicolor; however, the noted differences did not exceed $65 \%$ of the concentrations measured in these species in the Chałupy region (Table 4). As in the case of C. glaucum and insect larvae, the higher $\mathrm{Hg}_{\mathrm{TO}}$ levels, measured in Oligochaetes, Corophium sp. and $H$. diversicolor in Osłonino, were associated with increased $\mathrm{Hg}_{\text {тот }}$ concentration in their diet (Table 3; Table SIII) - the surface sediments in the case of Oligochaetes (van de Bund et al. 1994; Rodrigues and Reynoldson 2011); suspended matter, microalgae and sediments in the case of Corophium sp. (Olenin and Daunys 2005; Riisgård and Schotge 2007); and sediments and microalgae in the case of $H$. diversicolor (Olivier et al. 1995; Olenin and Daunys 2005).

\section{Part of the gulf under little land influence-Chatupy}

In the area of the Chałupy station, the inflow of material from land-based sources was limited. This is confirmed by the lower concentration of SPM and the lower share of organic matter and fine particle fraction in surface sediments, in comparison with Osłonino (Table 1). What is important, the Chałupy site was not only characterised by a different amount of matter compared to the Osłonino site but, more importantly, typically marine origin (median $\delta^{13} \mathrm{C}-22.0 \%$; median $\delta^{15} \mathrm{~N}$ 3.1\%o; median $\mathrm{C}_{\mathrm{ORG}} / \mathrm{N}_{\mathrm{TOT}}$ 8.1) (Jędruch et al. 2017) (Table SI). This material comes from in situ primary production (mainly microalgae and phytoplankton) but is also transported from the deeper parts of the Gulf of Gdańsk (Jędruch et al. 2017). The station in Chałupy was also rich in bottom vegetation-macroalgae and vascular plants. This ensured that the biomass of phytobenthos in the Chałupy region was almost double that of the station in Osłonino (Bełdowska et al. 2016b). This resulted in richer species composition and increased biomass of grazing zoobenthic organisms, such as molluscs: Peringia sp., T. fluviatilis and R. labiata and crustaceans: Idotea sp. and L. hookeri, in comparison with the station at Osłonino (Table 2; Table SII).

Among the taxa noted at both stations, higher $\mathrm{Hg}_{\mathrm{TOT}}$ concentrations at the Chałupy station in comparison to the Osłonino station were observed in four taxa: M. arenaria, Idotea sp., Peringia sp. and Gammarus sp. (Fig. 2; Table 4). The greatest difference was observed in the suspensivore $M$. arenaria, for which the $\mathrm{Hg}_{\text {TOT }}$ concentrations at the Chałupy station (median $65.7 \mathrm{ng} \mathrm{g}^{-1}$ ) were more than four times higher than at 
the station in Osłonino (median $14.0 \mathrm{ng} \mathrm{g}^{-1}$ ). Although $M$. arenaria is a suspension feeder which feeds on suspended matter and microalgae, similar to C. glaucum, it also feeds on detritus and organic matter deposited in sediments (Bacon et al. 1998; Olenin and Daunys 2005) (Table 2). $\mathrm{Hg}_{\text {TOT }}$ concentrations in this species increased together with the share of fine fraction in surface sediments $(R=0.81)$ and $\mathrm{Hg}_{\mathrm{TOT}}$ concentration in FLSM $(R=0.62)$ (Table SIII). Elevated $\mathrm{Hg}_{\mathrm{TOT}}$ concentrations in $M$. arenaria may be due to the fact that the dominant form of $\mathrm{Hg}$ in sediments in the Chałupy region was $\mathrm{Hg}$ adsorbed on the fine fraction of sediment $\left(\mathrm{Hg}_{\mathrm{FSF}}\right)$ (Table 4). This confirms the relationship between the concentration of $\mathrm{Hg}_{\mathrm{TOT}}$ in surface sediments and contents of the FSF $(R=0.80)$. This may indicate the removal of $\mathrm{Hg}$-rich fine fraction sediments deposited in the deeper parts of the Gulf of Gdańsk (e.g. as a consequence of upwelling) and their transport to the shallow Puck Lagoon (Jędruch et al. 2015; Jędruch et al. 2017). The other taxa which were characterised by slightly higher (about $10 \%) \mathrm{Hg}_{\mathrm{TOT}}$ concentrations at the Chałupy station were Idotea sp., Peringia sp., and Gammarus sp. (Fig. 2; Table 4). In the case of grazing Idotea sp. and Peringia sp. (Kamermans et al. 2002; Riera 2010), the elevated $\mathrm{Hg}_{\mathrm{TO}}$ concentration was correlated with the $\mathrm{Hg}_{\text {тот }}$ concentration in benthic macrophytes and suspended matter (Table 3; Table SIII). In the case of omnivorous Gammarus sp., no relationship was observed between the $\mathrm{Hg}_{\text {Tот }}$ in these taxa and in its potential food sources.

\section{Hg bioaccumulation and biomagnification}

The $\mathrm{Hg}_{\mathrm{TOT}}$ concentrations in macrofauna varied according to the diet of the analysed species. The highest $\mathrm{Hg}_{\mathrm{TOT}}$ levels, at both research stations, were measured in grazers (Fig. 3), which feed mostly on the microscopic algae, diatoms and detritus which createa biofilm that covers the macrophytes, rocks and other underwater surfaces (Table 2). High $\mathrm{Hg}_{\text {TOт }}$ concentrations in grazing macrofauna compared to other trophic groups were most distinct at the Chałupy station - the concentration of $\mathrm{Hg}_{\text {тот }}$ in grazers was about 2-fold higher than in those feeding on suspension and/or detritus and omnivores. In the case of the station in Osłonino, the concentration of $\mathrm{Hg}_{\text {TOт }}$ in grazers was similar to that measured in Chałupy ( $U$ Mann-Whitney test, $p=0.76$ ); however, the differences between grazers and other trophic groups in Osłonino were slight (Fig. 3). Such a distribution of
$\mathrm{Hg}_{\text {TOт }}$ concentrations in the macrozoobenthic trophic groups is related to the concentration of $\mathrm{Hg}_{\mathrm{TOT}}$ in the food components of the bottom fauna. This was confirmed by the concentrations of $\mathrm{Hg}_{\mathrm{TOT}}$ in benthic microorganisms forming the basic diet of grazers (epiphyton), which were higher than, for example, those measured in SPM - the main dietary component for filter organisms (Table 3). Additionally, as shown by studies conducted in the Puck Lagoon by Jankowska et al. (2018), an important source of food for grazers, along with microphytobenthos, may also be sedimentary organic matter (FLSM), in which concentrations were close to those measured in epilithic algae (Table SII). It may also be related to the form of $\mathrm{Hg}$ in the examined food sources - about $90 \%$ of $\mathrm{Hg}$ accumulated in benthic flora of the Puck Lagoon is in bioavailable labile form, while in the case of surface sediments only a half of $\mathrm{Hg}$ can be introduced to the trophic chain (Jędruch, unpublished).

\section{BSAF}

An additional indicator for a better understanding of the complex mechanism for incorporating $\mathrm{Hg}_{\mathrm{TO}}$ into the marine trophic chain is the BSAF, a single-compartment model that predicts partitioning between exposure medium (sediments) and biota (McGeer et al. 2003). This parameter differed statistically in the case of research stations in the Puck Lagoon ( $U$ Mann-Whitney test, $p=$ 0.00 ), with the values calculated for Chałupy being about four times higher (median 61.3) than in Osłonino (median 15.1) (Fig. 4). This was primarily related to the environmental conditions prevailing at the research stations. Numerous worldwide studies, in both marine and freshwater environments, indicate a significant effect of aerobic conditions on the uptake of $\mathrm{Hg}$ by organisms on the lowest trophic level (Sokołowski 2009; Wyn et al. 2009; Kidd et al. 2012). Lower oxygenation of surface sediments in the area of Osłonino is confirmed by lower values of potential $\mathrm{Eh}$ in comparison with the values measured in Chałupy (Table 1). Moreover, in the area of Osłonino, a complete depletion of oxygen and the temporary appearance of $\mathrm{H}_{2} \mathrm{~S}$ was noted periodically (Bełdowska et al. 2013; Jedruch et al. 2018a). As the oxidation of sediments decreases, the abundance of anaerobic bacteria increases, and this is accompanied by a drop in $\mathrm{Hg}$ concentration in pore waters (Bełdowska et al. 2013). As a consequence, the accumulation of $\mathrm{Hg}$ in zoobenthic organisms is limited. In addition to this, the limited accumulation of $\mathrm{Hg}$ in the 
Fig. 4 Biota-sediment accumulation factor (BSAF) of total mercury $\left(\mathrm{Hg}_{\mathrm{TOT}}\right)$ in the main trophic groups of macrozoobenthos of the coastal zone of the Puck Lagoon (southern Baltic Sea) in years 2011-2013

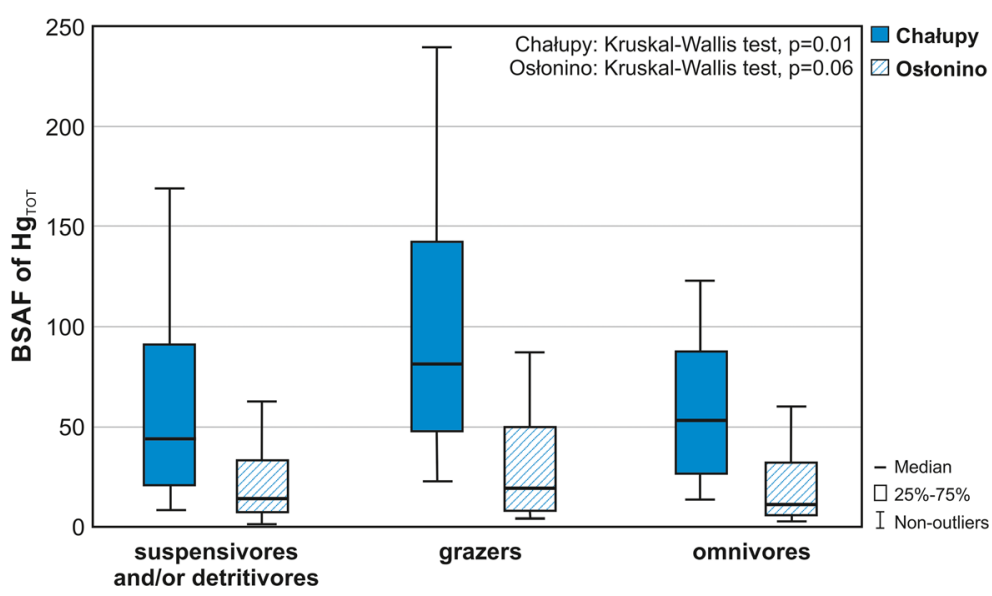

macrozoobenthos at Osłonino could be associated with lower $\mathrm{pH}$ and higher water temperature in comparison to Chałupy (Table 1), especially in the summer season (mean in the summer season $20.0^{\circ} \mathrm{C}$ and $17.8^{\circ} \mathrm{C}$, respectively). This was also indicated by the research results of Greenfield et al. (2001) and Lavoie et al. (2013). The higher temperature in Osłonino during the summer stimulated the growth of organisms (greater biomass of organisms at Osłonino than Chałupy), leading to the "dilution" of $\mathrm{Hg}$ accumulated in body tissues.

The limited accumulation of $\mathrm{Hg}$ in macrozoobenthos in Osłonino could also be connected to an increased inflow and accumulation of organic matter in the area of the station, as well as increased nutrient supply associated with increased surface runoff (Kidd et al. 2012; McGeer et al. 2003; Jędruch et al. 2017). This is confirmed by the results of experimental research conducted by Pickhardt et al. (2002), concerning the effect of the increased load of biogenic substances and subsequent algal blooms. More specifically, while algae effectively and rapidly concentrate both inorganic and organic $\mathrm{Hg}$, the metal burden per cell decreases in algal blooms. This results in diluted concentrations of bioavailable $\mathrm{Hg}$ in algae, thus limiting its transfer to the organisms which feed on it. Similar results were noted by Chouvelon et al. (2018) in the comparative study of two marine ecosystems, oligo- and mesotrophic ones. In the case of area with higher productivity, the bioaccumulation of $\mathrm{Hg}$ in medium-trophic level consumers was lower compared to the organisms from oligotrophic waters.

The comparison of BSAF values at two research stations showed the significant impact of the feeding mode and activity of macrofauna on the accumulation of $\mathrm{Hg}$. The bioaccumulation of $\mathrm{Hg}_{\text {TOT }}$, both at Chałupy and Osłonino, was found to be the greatest in the omnivorous group (Fig. 4), a group dominated by taxa burrowing deeply in sediments, such as $H$. diversicolor or Marenzelleria sp. (Leppakoski and Olenin 2000). Higher BSAF in burrowing macrofauna compared to epifauna living on the sediment's surface can be associated with the release of $\mathrm{Hg}$ accumulated in the deeper layers of sediments. Although the $\mathrm{Hg}$ in the deeper sediments occurs mostly as a stable $\mathrm{HgS}$, as a result of bioturbation and increased oxygen input, it may transform to bioavailable Hg sulphate (Bełdowski and Pempkowiak 2003).

\section{BMF}

$\mathrm{Hg}_{\text {TОт }}$ concentrations measured in individual elements of the coastal zone increased together with trophic level. The linear function of $\ln$-transformed $\mathrm{Hg}_{\text {TOT }}$ concentration in individual environmental elements and values of $\delta^{15} \mathrm{~N}$ representing the trophic position $(R=0.51$, $p<0.001$ ) (according to Eq. 9) points to $\mathrm{Hg}$ biomagnification in the trophic chain, as testified to by the positive slope coefficient value for the function (Lavoie et al. 2013; Riyadi et al. 2015). This coefficient, also known as the trophic magnification slope (TMS) (Nfon et al. 2008; Lavoie et al. 2013), calculated for data from the Puck Lagoon, was 0.22 (Table 5). This value was within the range of results obtained by other researchers of aquatic food webs $(0.01-0.40)$ (i.e. Chen et al. 2000; Campbell et al. 2003; Al-Reasi et al. 2007; Lavoie et al. 2010; Chouvelon et al. 2018). The TMS in Puck Lagoon was higher than the mean (0.16) based on a compilation of data from more than 200 aquatic environments worldwide. However, the TMS in the Puck Lagoon was close to the mean calculated only for 
Table 5 Comparison of trophic magnification slope (TMS) of total mercury $\left(\mathrm{Hg}_{\mathrm{TOT}}\right)$ in the marine systems around the world

\begin{tabular}{|c|c|c|c|c|}
\hline Zone & Region & Country & TMS & Reference \\
\hline \multirow[t]{4}{*}{ Tropical } & Gulf of Oman & Oman & 0.07 & Al-Reasi et al. 2007 \\
\hline & Sepetiba Bay & Brazil & 0.07 & Bisi et al. 2012 \\
\hline & Jakarta Bay & Indonesia & 0.07 & Riyadi et al. 2015 \\
\hline & Guanabara Bay & Brazil & 0.18 & Bisi et al. 2012 \\
\hline \multirow[t]{12}{*}{ Temperate } & Azores & Portugal & 0.01 & Newman et al. 2011 \\
\hline & Gulf of Lion & France & 0.11 & Chouvelon et al. 2018 \\
\hline & Masan Bay & Korea & 0.12 & Kim et al. 2012 \\
\hline & Northern Yellow Sea & China & 0.13 & Zhao et al. 2013 \\
\hline & Gulf of Mexico & USA & 0.17 & Cai et al. 2007 \\
\hline & Gulf of St Lawrence & Canada & 0.17 & Lavoie et al. 2010 \\
\hline & Puck Lagoon & Poland & 0.22 & This study \\
\hline & Bird Island & South Georgia & 0.27 & Anderson et al. 2009 \\
\hline & Australian waters & Australia & 0.31 & Pethybridge et al. 2012 \\
\hline & Sanriku coast & Japan & 0.33 & Riyadi et al. 2015 \\
\hline & Gulf of the Farallones & USA & 0.33 & Jarman et al. 1996 \\
\hline & Bay of Biscay & France & 0.35 & Chouvelon et al. 2018 \\
\hline \multirow[t]{9}{*}{ Polar } & West Greenland & Greenland & 0.08 & Rigét et al. 2007 \\
\hline & Nasaruvaalik & Greenland & 0.10 & Clayden et al. 2015 \\
\hline & Alaskan Arctic & USA & 0.10 & Fox et al. 2017 \\
\hline & Lancaster & Canada & 0.14 & Atwell et al. 1998 \\
\hline & Northwater Polynya & Canada & 0.20 & Campbell et al. 2005 \\
\hline & Kongsfjorder, Svalbard & Norway & 0.21 & Jæger et al. 2009 \\
\hline & Amundsen Shelf & Canada & 0.25 & Loseto et al. 2008 \\
\hline & Icelandic waters & Iceland & 0.26 & McMeans et al. 2010 \\
\hline & Chukchi Sea & USA & 0.29 & Dehn et al. 2006 \\
\hline
\end{tabular}

marine systems (0.20) (Lavoie et al. 2013) and particular marine systems located in the temperate zone $(0.22)$ (Table 5; Fig. 6). The mean $\mathrm{Hg}$ biomagnification factor (BMF) calculated on the basis of the TMS value (Eq. 10 ) in the trophic web of the Puck Lagoon was 2.2 and was about $20 \%$ higher than the global average (1.8). This is connected to the relatively low productivity of the Puck Lagoon system, as well as to conditions related to the latitude - the higher values of BMF were calculated in temperate and polar regions in comparison to the tropic zone (Sokołowski et al. 2012; Lavoie et al. 2013; Riyadi et al. 2015).

Geographical differences in the $\mathrm{Hg}$ transfer rates were also reported for the research stations in the inner coastal zone of the Puck Lagoon. The TMS of Hg, calculated on the basis of $\mathrm{ln}$-transformed $\mathrm{Hg}$ concentrations and $\delta^{15} \mathrm{~N}$ values, in Osłonino was lower (0.18) in comparison to Chałupy (0.27) (Fig. 5), which indicated a different biomagnification power of $\mathrm{Hg}$ in the trophic chains at these station. The biomagnification factor of $\mathrm{Hg}$ calculated on the basis of TMS values was 1.8 in Osłonino and 2.5 in Chałupy (Fig. 6). These differences are related not only to the structure of the trophic web and to the dietary habits of primary consumers (Chouvelon et al. 2018) but also to the different environmental conditions prevailing at research stations in the coastal zone (Wyn et al. 2009; Kidd et al. 2012). Although the concentration of $\mathrm{Hg}$ in benthic organisms at the station in Osłonino was slightly higher than the station in Chałupy (Fig. 2; Tables 3 and 4), the rate of $\mathrm{Hg}$ biomagnification from food sources to consumers in Osłonino was slower. This could also be related to 


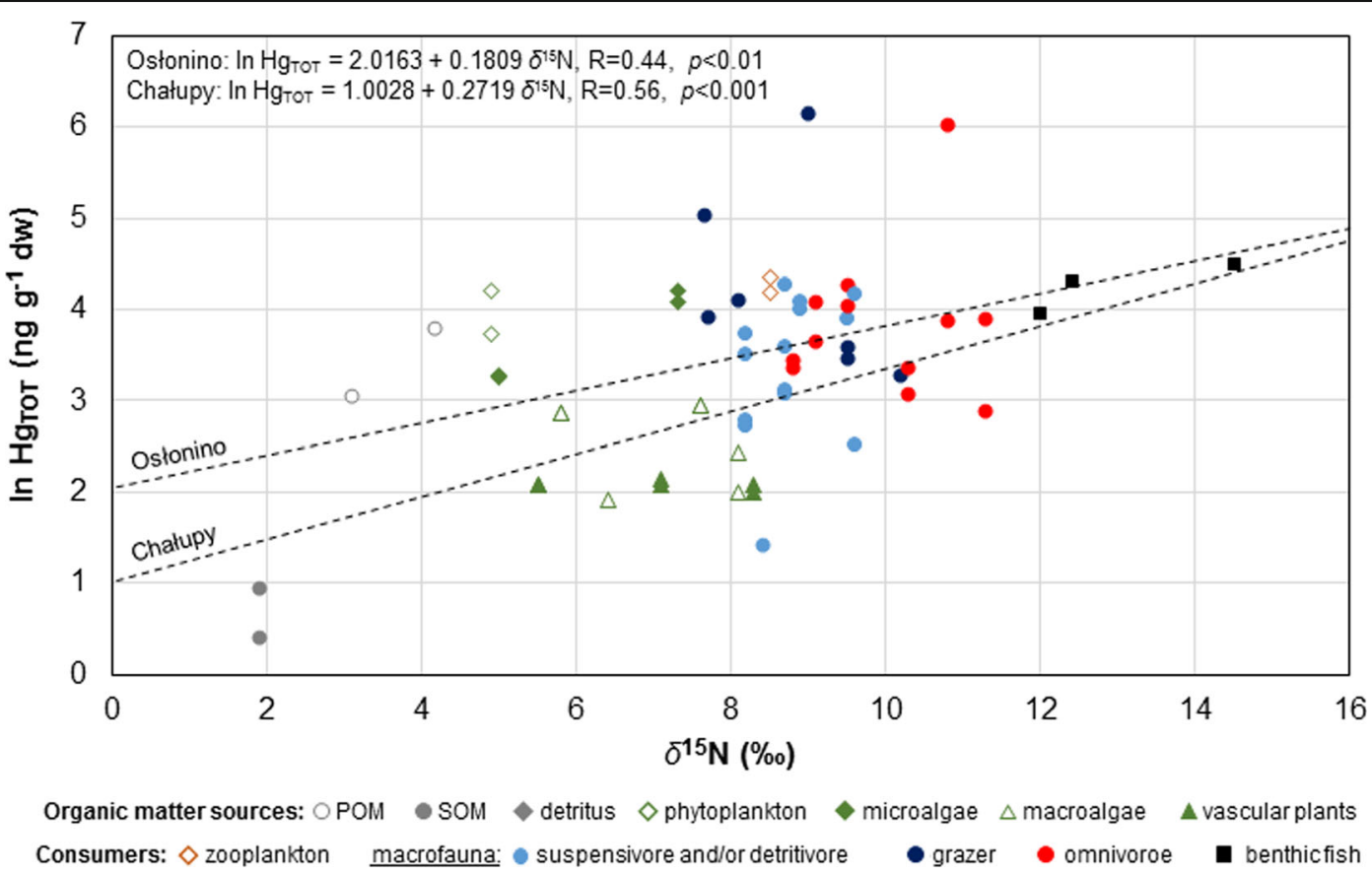

Fig. 5 Trophic magnification slope (TMS) of total mercury $\left(\mathrm{Hg}_{\text {Tот }}\right)$ calculated on the basis of the relationship between median values of $\ln$-transformed $\mathrm{Hg}_{\text {TOT }}$ concentrations and $\delta^{15} \mathrm{~N}$ in various components of the benthic food web from the sampling

greater productivity in the Osłonino region, resulting in a higher biomass of producers and macrozoobenthic organisms, and also suspended organic matter (Bełdowska and Kobos 2016; Jędruch et al. 2017). Similar impact of the productivity of marine systems on $\mathrm{Hg}$ biomagnification was observed in the Mediterranean and Atlantic waters (Chouvelon et al. 2018). The trophic factor of waters strongly influences the $\mathrm{Hg}$ biomagnification, through the "biodilution effect" stations (Osłonino and Chałupy) in the coastal zone of the Puck Lagoon in years 2011-2013. The data on the $\delta^{15} \mathrm{~N}$ can be found in Table SI and Fig. SI

(Pickhardt et al. 2002). It is due to the higher number and higher surface area/volume ratio (i.e. size) of cells at the base of systems with high productivity. This configuration is less favourable to an efficient uptake of $\mathrm{Hg}$ by cells, whose the lower $\mathrm{Hg}$ burden is then transferred to consumers. Moreover, in areas with low primary production, where cells are thus less abundant and potentially contain higher $\mathrm{Hg}$ burden, primary consumers probably consume virtually all of them (Chouvelon
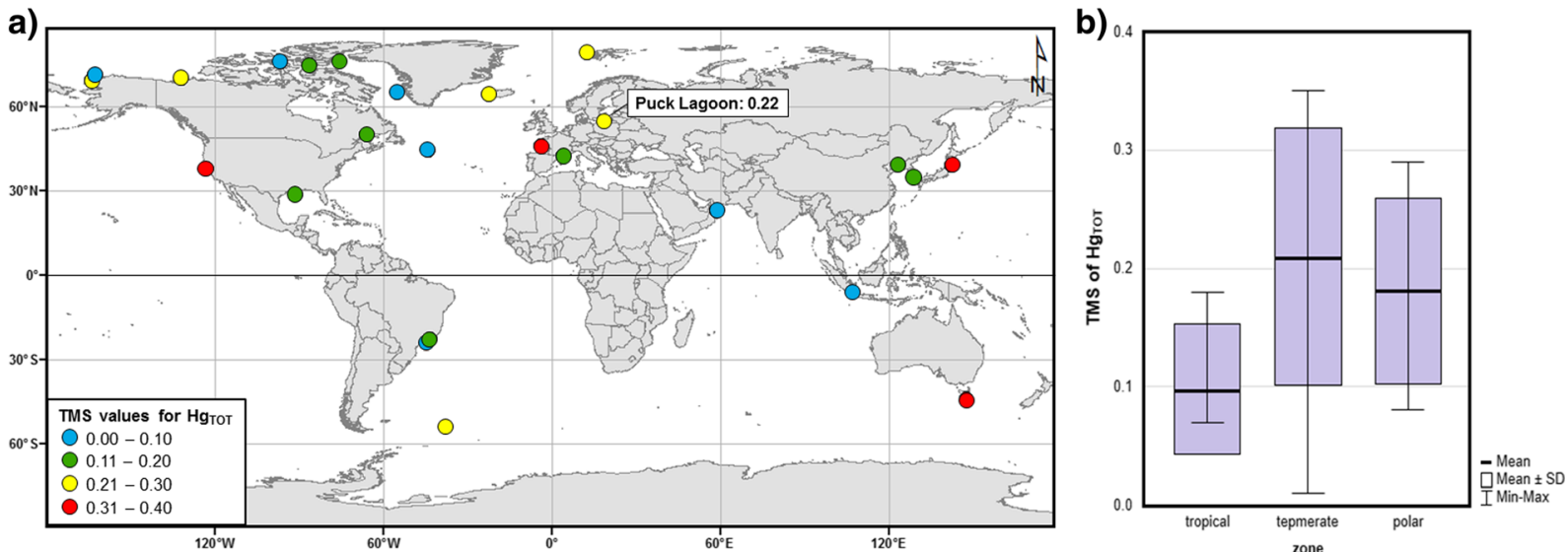

Fig. 6 Trophic magnification slope (TMS) of total mercury $\left(\mathrm{Hg}_{\mathrm{TOT}}\right)$ in the marine systems around the world (a) together with basic statistics of TMS depending on the latitude (b) based on literature data (data sources can be found in Table 5) 
et al. 2018). Biodilution of $\mathrm{Hg}$ in the macrofauna also occurs as a result of to the high abundance of detrital and organic particles and growth dilution (fast growth rates for longer lived organisms), across several trophic levels (Kidd et al. 2012). In addition to this, in waters of a lower $\mathrm{pH}$, the lower $\mathrm{Hg}$ biomagnification may be due to the effect of water temperature or chemistry on the methylation of inorganic $\mathrm{Hg}$ to methylmercury and/or its availability to primary producers and consumers (Wyn et al. 2009; Chouvelon et al. 2018). Numerous studies have demonstrated the relationship between limited $\mathrm{Hg}$ biomagnification in the initial links of the trophic chain and low oxygen conditions, which are likely to occur at organic-rich regions of the inner Puck Lagoon, such as Osłonino. The periodic deficiency of oxygen and temporal presence of hydrogen sulphide at this station likely influenced $\mathrm{Hg}$ transfer in benthic communities by altering $\mathrm{Hg}$ bioavailability (Sokołowski 2009).

\section{Temporal trends}

Species composition analysis demonstrated the restructuring of macrozoobenthos in the Puck Lagoon coastal zone, in comparison with previous years (e.g. Legeżyńska and Wiktor 1981; Kotwicki 1997; Janas and Kendzierska 2014). The observed changes may entail far-reaching alterations in the nature and rate of flow of chemicals (and hence $\mathrm{Hg}$ ) through the various trophic levels and therefore the whole ecosystem.

In the case of the station in Osłonino, a particularly important observation is the increased percentage over the past decade or so of Crustacea in the macrozoobenthos biomass. In 2011-2013, this percentage share was about 2.5 times higher than in the early 1990s (Kotwicki 1997) (Table SII), and the concentration of $\mathrm{Hg}_{\mathrm{TO}}$ in this subphylum (mean $74.8 \mathrm{ng} \mathrm{g}^{-1}$ ) was found to be almost $30 \%$ higher than the metal level measured in all other macrofauna species in the area of this station (mean $59.6 \mathrm{ng} \mathrm{g}^{-1}$ ). Continuation of this upward trend in the percentage of Crustacea in the macrozoobenthos biomass, together with a decreasing share of groups with lower $\mathrm{Hg}_{\mathrm{TOT}}$ concentrations (e.g. Bivalvia, Polychaeta) (Table 4), may increase a load of metal entering the trophic chain. Crustaceans such as Gammarus sp., Idotea sp. and Corophium sp. are important dietary constituents of the majority of Puck Lagoon fish, their offspring and higher-trophic-level crustaceans such as the Crangon crangon or Palaemon sp. varieties of shrimp (Morawski 1978; Legeżyńska and Wiktor 1981).

In the coastal zone at Chałupy, changes to the structure of zoobenthos became apparent especially in the case of Bivalvia. In the area of that station, the average share of this class of organisms in the biomass of bottom macrofauna in the years 2011-2013 was over two times lower than in 1992-1993 (Kotwicki 1997). Bivalvia once represented roughly half of the benthic macrofauna biomass, but now, their average share does not exceed $20 \%$ (Table SII). The drop in biomass of molluscs, with their high filtration capacity, can lead to changes in the flow rate of matter in the ecosystem, including an increased rate of accumulation of organic matter (and thus $\mathrm{Hg}$ ) in bottom sediments (Błędzki and Kruk-Dowgiałło 1983). The concentration of $\mathrm{Hg}_{\mathrm{TO}}$ measured in Bivalvia (mean $42.2 \mathrm{ng} \mathrm{g}^{-1}$ ) was about $40 \%$ lower than the average metal concentration in macrozoobenthos in the Chałupy region (mean $65.7 \mathrm{ng} \mathrm{g}^{-1}$ ) (Table 4). The decline of Bivalvia in macrozoobenthos biomass was accompanied by an increase in the share of taxa with higher than average (in terms of bottom fauna) $\mathrm{Hg}_{\mathrm{TOT}}$ concentrations (e.g. Oligochaeta, Gastropoda). As with the growing share of Crustacea in the area of Osłonino, this may lead to an increase in the load of $\mathrm{Hg}_{\mathrm{TOT}}$ conveyed to higher trophic levels.

Changes in species composition and macroozoobenthos structure are also related to the emergence of new species, which most often reach the Baltic with the ballast water of ships (Leppakoski and Olenin 2000). Some non-indigenous species such as $M$. arenaria and A. improvisus were introduced into the Baltic Sea more than a hundred years ago, and their population in the basin having since stabilised has become a permanent feature of the macrofauna. However, more than half of the new species have been introduced into the Baltic post-1950, and their populations are now dynamically developing and colonising new areas. These include, among others, R. harrisii and Gammarus tigrinius, recorded in the Baltic Sea for the first time in 1951 and 1975, respectively. Another important species is the genus Marenzelleria sp., first observed in the Baltic Sea in the mid-1980s (Leppakoski and Olenin 2000; Janas and Kendzierska 2014).

In collected macrofauna, four non-native species were identified-M. arenaria, Marenzelleria sp., $R$. harrisii and A. improvisus (Table SII). The highest concentration of $\mathrm{Hg}$ among these non-indigenous species was measured in Marenzelleria sp., for which the average metal concentration was $63 \%$ higher than the 
mean $\mathrm{Hg}$ concentration in all analysed species and $41 \%$ higher than the mean $\mathrm{Hg}$ concentration measured in non-native species. The Marenzelleria genus was the latest of the non-native species to appear, which was first identified in the area of the Polish coast as recently as 1988 (Gruszka 1991). In the Puck Lagoon area, the highest density of Marenzelleria occurs at depths of over $4 \mathrm{~m}$, but this species has also appeared sporadically in shallow areas in the past. In previous studies, no taxa were observed in the shallow part $(<1 \mathrm{~m})$ of the coastal zone in Chałupy and Osłonino (Kotwicki 1997; Janas and Kendzierska 2014). In other shallow areas of the coastal zone, where the presence of Marenzelleria was detected at a depth of less than $1 \mathrm{~m}$, the average abundance of the species between 1991 and 1992 was more than three times lower than in 2011-2013, while its average biomass was 10 -fold less than reported by the authors of this work (Kotwicki 1997). This suggests that the Marenzelleria genus has settled into ever more shallow bottom areas, and the expansion of this species in the aquifer, as well as its individual traits, can significantly influence the transfer of $\mathrm{Hg}$ in the ecosystem. Marenzelleria penetrates into the sediment to a depth of $40 \mathrm{~cm}$, thereby increasing the thickness of the populated sediment layer and the maximum depth of bioturbation. In addition, Marenzelleria is reported to migrate by active swimming and such movement may serve as an important link in energy transfer between pelagic and benthic subsystems (Bochert et al. 1996; Leppakoski and Olenin, 2000). As a result, Marenzelleria mobilises Hg-rich organic matter deposited in deeper sediment. In addition to this, it is characterised by rapid spread due to its high capacity for reproduction, rapid growth and longevity of life (as with the 2- to 3-year lifespan of Polychaeta) (Leppakoski and Olenin 2000), all of which facilitates the accumulation of $\mathrm{Hg}$. The high concentration of $\mathrm{Hg}$ in the dynamically spreading Marenzelleria genus can also indirectly affect human health, particularly as this species is an important dietary component of flatfish and perch, both of which are caught for human consumption (Warzocha 2009).

\section{Summary}

In the presented study, the effect of ecosystems' characteristic on the bioaccumulation and biomagnification of $\mathrm{Hg}$ in marine the trophic chain was demonstrated. The previous works relating to this topic concerned mainly freshwater ecosystems (i.e. Campbell et al. 2005; Wyn et al. 2009; Kidd et al. 2012), while comparative studies for marine environment are still rare (Lavoie et al. 2013; Chouvelon et al. 2018). In addition, the previous research was usually conducted in systems characterised by higher productivity and biodiversity compared to the Baltic Sea.

Results of our ecosystem-comparative study showed that although the stations in the Puck Lagoon were situated in close proximity, the concentrations of $\mathrm{Hg}$ in the analysed benthic components, as well as its bioaccumulation and biomagnification in the trophic chain were different. An important factor shaping the level of $\mathrm{Hg}$ in investigated organisms was the inflow of allochthonous organic matter to the coastal waters. The increased inflow of terrigenous matter from land together with the shape of the coastline and sea bottom, which were conducive to the accumulation of organic matter near the shore, resulted in an increase in $\mathrm{Hg}_{\mathrm{TOT}}$ concentration in suspended particulate matter and primary microproducers (epiphytes, phytoplankton). This led to an increase in the concentration of $\mathrm{Hg}_{\mathrm{TOT}}$ in filter feeders. In the case of an area subjected to the inflow of marine organic matter, with Hg-rich fine organic particles coming from deeper regions of the bottom, an increase in $\mathrm{Hg}_{\text {Tот }}$ concentrations was observed in organisms feeding on sediment particles. Therefore, it is particularly important to take into account differences in the quality and quantity of organic matter at research stations.

An important factors contributing to the increase of the $\mathrm{Hg}_{\text {тот }}$ load entering the trophic chain were environmental parameters. The physico-chemical characteristics of the environment, as well as its productivity, were found to be of particular importance in terms of the BSAF and BMF. Weaker uptake and trophic transfer of $\mathrm{Hg}_{\text {TOт }}$ was noted in the area with poorer oxygen conditions, lower $\mathrm{pH}$ and higher temperature of the near-bottom water. The introduction of $\mathrm{Hg}_{\mathrm{TO}}$ into the trophic chain may also be aggravated by the rebuilding of the macrofauna structure (increase in the biomass of species with high $\mathrm{Hg}_{\text {Tот }}$ concentration, with a simultaneous decrease of taxa with $\mathrm{Hg}_{\mathrm{TO}}$ level) and the expansion of non-native species. From the point of view of human health, the increase of $\mathrm{Hg}$ concentration in fish and invertebrates caught for consumption, one of the main routes by which $\mathrm{Hg}$ enters the body, is particularly dangerous. This is especially important for populations with a traditionally high dietary 
intake of fish and seafood, as they are particularly vulnerable to $\mathrm{Hg}$ poisoning.

Acknowledgements The authors wish to express their gratitude to Adam Sokołowski (Institute of Oceanography, University of Gdańsk) and Emilia Jankowska (Institute of Oceanology, Polish Academy of Sciences) for their help in the interpretation of biological data on macrozoobenthos communities.

Funding information This study has been performed within the framework of a National Science Centre project: No. 2011/01/ B/ST10/07697.

Open Access This article is distributed under the terms of the Creative Commons Attribution 4.0 International License (http:// creativecommons.org/licenses/by/4.0/), which permits unrestricted use, distribution, and reproduction in any medium, provided you give appropriate credit to the original author(s) and the source, provide a link to the Creative Commons license, and indicate if changes were made.

Publisher's note Springer Nature remains neutral with regard to jurisdictional claims in published maps and institutional affiliations.

\section{References}

Al-Reasi, H. A., Ababneh, F. A., \& Lean, D. R. (2007). Evaluating mercury biomagnification in fish from a tropical marine environment using stable isotopes (delta C-13 and delta N-15). Environmental Toxicology and Chemistry, 26, 15721581. https://doi.org/10.1897/06-359R.1.

Anderson, O. R. J., Phillips, R. A., McDonald, R. A., Shore, R. F., McGill, R. A. R., \& Bearhop, S. (2009). Influence of trophic position and foraging range on mercury levels within a seabird community. Marine Ecology Progress Series, 375, 277-288. https://doi.org/10.3354/meps07784.

Attrill, M. J., Rundle, S. D., Fraser, A., \& Power, M. (2009). Oligochaetes as a possible entry route for terrigenous organic carbon into estuarine benthic food webs. Marine Ecology Progress Series, 384, 147-157. https://doi.org/10.3354 /meps08019.

Atwell, L., Hobson, K. A., \& Welch, H. E. (1998). Biomagnification and bioaccumulation of mercury in an Arctic marine food web: insights from stable nitrogen isotope analysis. Canadian Journal of Fisheries and Aquatic Sciences, 55, 1114-1121. https://doi.org/10.1139/f98-001.

Bacon, G. S., MacDonald, B. A., \& Ward, J. E. (1998). Physiological responses of infaunal (Mya arenaria) and epifaunal (Placopecten magellanicus) bivalves to variations in the concentration and quality of suspended particles: I. Feeding activity and selection. Journal of Experimental Marine Biology and Ecology, 219, 105-125. https://doi. org/10.1016/S0022-0981(97)00177-9.

Barnes, R. S. K. (1994). The brackish-water fauna of northwestern Europe (p. 304). New York: Cambridge University Press.
Bełdowska, M., Jędruch, A., Słupkowska, J., Saniewska, D., \& Saniewski, M. (2015). Macrophyta as a vector of contemporary and historical mercury from the marine environment to the trophic web. Environmental Science and Pollution Research, 22, 5228-5240.. https://doi.org/10.1007/s11356014-4003-4

Bełdowska, M. (2016). Review of mercury circulation changes in the coastal zone of Southern Baltic Sea. In M. Marghany (Ed.), Applied studies of coastal and marine environments (pp. 109-124). INTECH. https://doi.org/10.5772/61991.

Bełdowska, M., \& Falkowska, L. (2016). Mercury in marine fish, mammals, seabirds, and human hair in the coastal zone of the southern Baltic. Water, Air, \& Soil Pollution, 227, 52. https://doi.org/10.1007/s11270-015-2735-5

Bełdowska, J., \& Kobos, J. (2016). Mercury concentration in phytoplankton in response to warming of an autumn-winter season. Environmental Pollution, 215, 38-47. https://doi. org/10.1016/j.envpol.2016.05.002.

Bełdowska, M., \& Mudrak-Cegiołka, S. (2017). Mercury concentration variability in the zooplankton of the southern Baltic coastal zone. Progress in Oceanography, 159, 73-85. https://doi.org/10.1016/j.pocean.2017.09.009.

Bełdowska, M., Jędruch, A., Bełdowski, J., \& Szubska, M. (2013). Mercury concentration in the sediments as a function of changing climate in coastal zone of Southern Baltic Seapreliminary results. E3S Web of Conferences, 1, 06002. https://doi.org/10.1051/e3sconf/20130106002.

Bełdowska, M., Jędruch, A., Słupkowska, J., Saniewska, D., \& Saniewski, M. (2014a). Macrophyta as a vector of contemporary and historical mercury from the marine environment to the trophic web. Environmental Science and Pollution Research, 22, 5228-5240. https://doi.org/10.1007/s11356014-4003-4.

Bełdowska, M., Saniewska, D., \& Falkowska, L. (2014). Factors influencing variability of mercury input to the southern Baltic Sea. Marine Pollution Bulletin, 86, 283-290. https://doi. org/10.1016/j.marpolbul.2014.07.004.

Bełdowska, M., Jędruch, A., Łęczyński, L., Saniewska, D., \& Kwasigroch, U. (2016a). Coastal erosion as a source of mercury into the marine environment along the Polish Baltic shore. Environmental Science and Pollution Research, 23, 16372-16382. https://doi.org/10.1007 /s11356-016-6753-7.

Bełdowska, M., Jędruch, A., Zgrundo, A., Ziółkowska, M., Graca, B., \& Gębka, K. (2016b). The influence of cold season warming on the mercury pool in coastal benthic organisms. Estuarine, Coastal and Shelf Science, 171, 99-105. https://doi.org/10.1016/j.ecss.2016.01.033.

Bełdowski, J., \& Pempkowiak, J. (2003). Horizontal and vertical variabilities of mercury concentration and speciation in sediments of the Gdańsk Basin, Southern Baltic Sea. Chemosphere, 52, 645-654. https://doi.org/10.1016/S0045655(03)00246-7.

Bisi, T. L., Lepoint, G., Azevedo, A. D., Dorneles, P. R., Flache, L., Das, K., Malm, O., \& Lailson-Brito, J. (2012). Trophic relationships and mercury biomagnification in Brazilian tropical coastal food webs. Ecological Indicators, 18, 291-302. https://doi.org/10.1016/j.ecolind.2011.11.01.

Błędzki, L., \& Kruk-Dowgiałło, L. (1983). Long-term alterations of the structure of the Puck Bay benthos. Warszawa: Man and the Environment, 7, 79-83. 
Bochert, R., Fritsche, D., \& Burckhardt, R. (1996). Influence of salinity and temperature on growth and survival of the planktonic larvae of Marenzelleria viridis (Polychaete, Spionidae). Journal of Plankton Research, 18, 1239-1251. https://doi. org/10.1093/plankt/18.7.1239.

Braune, W., \& Guiry, M. D. (2011). Seaweeds. A colour guide to common benthic Green, Brown and red algae of the world's oceans (p. 601). Köenigstein: Koeltz Scientific Books.

Broman, D., Rolff, C., Näf, C., Zebühr, Y., Fry, B., \& Hobbie, J. (1992). Using ratios of stable nitrogen isotopes to estimate bioaccumulation and flux of polychlorinated dibenzo-pdioxins (PCDDs) and dibenzofurans (PCDFs) in two food chains from the Northern Baltic. Environmental Toxicology and Chemistry, 11, 331-345. https://doi.org/10.1002 /etc.5620110307.

Cai, Y., Rooker, J. R., Gill, G. A., \& Turner, J. P. (2007). Bioaccumulation of mercury in pelagic fishes from the northern Gulf of Mexico. Canadian Journal of Fisheries and Aquatic Sciences, 64, 458-469. https://doi.org/10.1139/f07017.

Campbell, L. M., Hecky, R. E., Nyaundi, J., Muggide, R., \& Dixon, D. G. (2003). Distribution and food-web transfer of mercury in Napoleon and Winam gulfs, Lake Victoria, East Africa. Journal of Great Lakes Research, 29, 267-282. https://doi.org/10.1016/S0380-1330(03)70554-1.

Campbell, L. M., Norstrom, R. J., Hobson, K. A., Muir, D. C. G., Backus, S., \& Fisk, A. T. (2005). Mercury and other trace elements in a pelagic Arctic marine food web (Northwater Polynya, Baffin Bay). Science of the Total Environment, 351, 247-263. https://doi.org/10.1016/j.scitotenv.2005.02.043.

Chen, C. Y., Stemberg, R. S., Klaude, B., Blum, J. D., Pickhardt, P. S., \& Folt, C. L. (2000). Accumulation of heavy metals in food web components across a gradient of lakes. Limnology and Oceanography, 45, 1525-1536. https://doi.org/10.4319 /lo.2000.45.7.1525.

Chouvelon, T., Cresson, P., Bouchoucha, M., Brach-Papa, C., Bustamante, P., Crocher, S., Marco-Miralles, F., Thomas, B., \& Knoery, J. (2018). Oligotrophy as a major deliver of mercury bioaccumulation in medium-to high trophic level consumers: a marine ecosystem-comparative study. Environmental Pollution, 233, 844-854. https://doi. org/10.1016/j.envpol.2017.11.05.

Clayden, M. G., Arsenault, L. M., Kidd, K. A., O’Driscoll, N. J., \& Mallory, M. L. (2015). Mercury bioaccumulation and biomagnification in a small Arctic polynya ecosystem. Science of the Total Environment, 509-510, 206-215. https://doi.org/10.1016/j.scitotenv.2014.07.087

Dehn, L. A., Follmann, E. H., Thomas, D. L., Sheffield, G. G., Rosa, C., Duffy, L. K., \& O'Hara, T. M. (2006). Trophic relationships in an Arctic food web and implications for trace metal transfer. Science of the Total Environment, 362, 103123. https://doi.org/10.1016/j.scitotenv.2005.11.012.

Durai, K., \& Pandiyan, G. (2011). Method for the isolation of epiphytic algae. International Journal of Current Science, 1, 107-108.

Fox, A. L., Trefry, J. H., Trocine, R. P., Dunton, K. H., Lasorsa, B. K., Konar, B., Ashjian, C. J., \& Cooper, L. W. (2017). Mercury biomagnification in food webs of the northeastern Chukchi Sea, Alaskan Arctic. Deep Sea Research Part II: Topical Studies in Oceanography, 144, 63-77. https://doi. org/10.1016/j.dsr2.2017.04.020.
Frörstner, U., \& Wittman, G. (1981). Metal pollution in the aquatic environment (p. 488). Berlin: Springer. https://doi. org/10.1007/978-3-642-69385-4.

Fry, B. (2006). Stable isotope ecology (p. 308). New York: Springer-Verlag. https://doi.org/10.1007/0-387-33745-6.

Graca, B., Staniszewska, M., Zakrzewska, D., \& Zalewska, T. (2016). Reconstruction of the pollution history of alkylphenols (4-tert-octylphenol, 4-nonylphenol) in the Baltic Sea. Environmental Science and Pollution Research International, 23, 11598-11610. https://doi.org/10.1007 /s11356-016-6262-8.

Greenfield, B. K., Hrabik, T. R., Harvey, C. J., \& Carpenter, S. R. (2001). Predicting mercury levels in yellow perch: use of water chemistry, trophic ecology, and spatial traits. Canadian Journal of Fisheries and Aquatic Sciences, 58, 1419-1429. https://doi.org/10.1139/f01-088.

Gruszka, P. (1991). Marenzelleria viridis (Verrill, 1873) (Polychaeta-Spionidae) - a new component of shallow water benthic community in the Southern Baltic. Acta Ichthyologica et Piscatoria, 21, 57-65.

Hansson, S., Hobbie, J. E., Elmgren, R., Larsson, U., Fry, B., \& Johansson, S. (1997). The stable nitrogen isotope ratio as a marker of food-web interactions and fish migration. Ecology, 78, 2249-2257. https://doi.org/10.2307/2265961.

Heessen, H. J. L., Daan, N., \& Ellis, J. R. (2015). Fish atlas of the Celtic Sea, North Sea, and Baltic Sea (p. 572). Zeist: KNNV Publishing.

HELCOM. (1988). Guidelines for the Baltic monitoring programme for the third stage. Baltic Sea Environment Proceedings, 27, 161.

HELCOM. (2010). Hazardous substances in the Baltic Sea. An integrated thematic assessment of hazardous substances in the Baltic Sea. Baltic Sea Environment Proceedings No. 120B.

Hobson, K. A., \& Welch, H. E. (1992). Determination of trophic relationships within a high Arctic marine food web using $\delta^{13} \mathrm{C}$ and $\delta^{15} \mathrm{~N}$ analysis. Marine Ecology Progress Series, 84, 9-18. https://doi.org/10.3354/meps084009.

Jackson, T. A. (1998). Mercury in aquatic ecosystem. In J. Langston \& M. J. Bebianno (Eds.), Metal metabolism in aquatic environment (pp. 178-249). London: Chapman \& Hall. https://doi.org/10.1007/978-1-4757-2761-6.

Jæger, I., Hop, H., \& Gabrielsen, G. W. (2009). Biomagnification of mercury in selected species from an Arctic marine food web in Svalbard. Sci Total Environ, 407, 4744-4751. https://doi.org/10.1016/j.scitotenv.2009.04.004.

Janas, U., \& Kendzierska, H. (2014). Benthic non-indigenous species among indigenous species and their habitat preferences in Puck Bay (southern Baltic Sea). Oceanologia, 56, 603-628. https://doi.org/10.5697/oc.56-3.603.

Jankowska, E. (2017). Structure and functioning of the benthic communities associated with macrophytes meadows in the Gulf of Gdańsk. Sopot: PhD Thesis, Institute of Oceanology, Polish Academy of Sciences.

Jankowska, E., Włodarska-Kowalczuk, M., Kotwicki, L., Bałazy, P., \& Kuliński, K. (2014). Seasonality in vegetation biometrics and its effects on sediment characteristics and meiofauna in Baltic seagrass meadows. Estuarine, Coastal and Shelf Science, 139, 159-170. https://doi.org/10.1016/j. ecss.2014.01.003. 
Jankowska, E., Michel, L. N., Zaborska, A., \& WłodarskaKowalczuk, M. (2016). Sediment carbon sink in lowdensity temperate eelgrass meadows (Baltic Sea). Journal of Geophysical Research-Biogeosciences, 121, 29182934. https://doi.org/10.1002/2016JG003424.

Jankowska, E., De Troch, M., Michel, L. N., Lepoint, G., \& Włodarska-Kowalczuk, M. (2018). Modification of benthic food web structure by recovering seagrass meadows, as revealed by trophic markers and mixing models. Ecological Indicators, 90, 28-37. https://doi.org/10.1016/j. ecolind.2018.02.054.

Jarman, W. M., Hobson, K. A., Sydeman, W. J., Bacon, C. E., \& McLaren, E. B. (1996). Influence of trophic position and feeding location on contaminant levels in the Gulf of the Farallones food web revealed by stable isotope analysis. Environmental Science \& Technology, 30, 654-660. https://doi.org/10.1021/es950392n.

Jędruch, A., Bełdowski, J., \& Bełdowska, M. (2015). Long-term changes and distribution of mercury concentrations in surface sediments of the Gdańsk Basin (Southern Baltic Sea). Journal of Soils and Sediments, 15, 2487-2497. https://doi. org/10.1007/s11368-015-1148-9.

Jędruch, A., Kwasigroch, U., Bełdowska, M., \& Kuliński, K. (2017). Mercury in suspended matter - origin, distribution and transport at the land-sea interface. Marine Pollution Bulletin, 118, 354-367. https://doi.org/10.1016/j. marpolbul.2017.03.019.

Jędruch, A., Bełdowska, M., \& Graca, B. (2018a). Seasonal variation in accumulation of mercury in the benthic macrofauna in a temperate coastal zone (Gulf of Gdańsk). Ecotoxicology and Environmental Safety, 164, 305-316. https://doi. org/10.1016/j.ecoenv.2018.08.040.

Jędruch, A., Bełdowska, M., Kwasigroch, U., Normant-Saremba, M., \& Saniewska, D. (2018b). Mercury fractionation in marine macrofauna using thermodesorption technique: method and its application. Talanta, 189, 534-542. https://doi. org/10.1016/j.talanta.2018.07.047.

Kamermans, P., Malta, E. J., Verschuure, J. M., Schrijvers, L., Lentz, F., \& Lien, A. T. A. (2002). Effect of grazing by isopods and amphipods on growth of Ulva sp. (Chlorophyta). Aquatic Ecology, 36, 425-433. https://doi. org/10.1023/A:1016551911754.

Karlson, A. M. L., Gorokhova, E., \& Elmgren, R. (2015). Do deposit-feeders compete? Isotopic niche analysis of an invasion in a species-poor system. Scientific Reports, 5, 9715. https://doi.org/10.1038/srep09715.

Kelly, M. G., \& Zgrundo, A. (2013). Potential for crosscontamination of benthic diatom samples when using toothbrushes. Diatom Research: The Journal of the International Society for Diatom Research, 28, 359-363. https://doi. org/10.1080/0269249X.2013.806959.

Khan, N. S., Vane, C. H., \& Horton, B. P. (2015). Stable carbon isotope and $\mathrm{C} / \mathrm{N}$ geochemistry of coastal wetland sediments as a sea-level indicator. In I. Shennan, A. J. Long, \& B. P. Horton (Eds.), Handbook of sea-level research (pp. 295311). Chichester: Wiley. https://doi.org/10.1002 /9781118452547.ch20.

Kidd, K. A., Muir, D. C. G., Evans, M. S., Wang, X., Whittle, M., Swanson, H. K., Johnston, T., \& Guilford, S. (2012). Biomagnification of mercury through lake trout (Salvelinus namaycush) food webs of lakes with different physical, chemical and biological characteristics. Science of the Total Environment, 438, 135-143. https://doi.org/10.1016/j. scitotenv.2012.08.057.

Kim, E., Kim, H., Shin, K. H., Kim, M. S., Kundu, S. R., Lee, B. G., \& Han, S. (2012). Biomagnification of mercury through the benthic food webs of a temperate estuary: Masan Bay, Korea. Environmental Toxicology and Chemistry, 31, 12541263. https://doi.org/10.1002/etc.1809.

Kolb, G. S., Ekholm, J., \& Hambäck, P. A. (2010). Effects of seabird nesting colonies on algae and aquatic invertebrates in coastal waters. Marine Ecology Progress Series, 417, 287400. https://doi.org/10.3354/meps08791.

Kotwicki, L. (1997). Macrozoobenthos of sandy littoral zone of the Gulf of Gdańsk. Oceanologia, 39, 447-460.

Kwasigroch, U., Bełdowska, M., Jędruch, A., \& Saniewska, D. (2018). Coastal erosion-a "new" land-based source of labile mercury to the marine environment. Environmental Science and Pollution Research, 25, 28682-28694. https://doi. org/10.1007/s11356-018-2856-7.

Lavoie, R. A., Hebert, C. E., Rail, J.-F., Braune, B. M., Yumvihoze, E., Hill, L. G., \& Lean, D. R. S. (2010). Trophic structure and mercury distribution in a Gulf of St. Lawrence (Canada) food web using stable isotope analysis. Science of the Total Environment, 408, 5529-5539. https://doi.org/10.1016/j.scitotenv.2010.07.053.

Lavoie, R. A., Jardine, T. D., Chumchal, M. M., Kidd, K. A., \& Campbell, L. M. (2013). Biomagnification of mercury in aquatic food webs: a worldwide meta-analysis. Environmental Science \& Technology, 47, 13385-13394. https://doi.org/10.1021/es403103t.

Legeżyńska E, Wiktor K, 1981. Fauna denna Zatoki Puckiej właściwej. Zesz Nauk.Wydz.BiNoZ UG 8:63-77 (in Polish).

Leppakoski, E., \& Olenin, S. (2000). Non-native species and rates of spread: lessons from the brackish Baltic Sea. Biological Invasions, 2, 151-163.

Loseto, L. L., Stern, G. A., Deibel, D., Connelly, T. L., Prokopowicz, A., Lean, D. R. S., Fortier, L., \& Ferguson, S. H. (2008). Linking mercury exposure to habitat and feeding behaviour in Beaufort Sea beluga whales. Journal of Marine Systems, 74, 1012-1024. https://doi.org/10.1016/j. jmarsys.2007.10.004.

Marković, V., Tomović, J., Atanacković, A., Kračun, M., Ilić, M., Nikolić, V., \& Paunović, M. (2015). Macroinvertebrate communities along the Velika Morava River. Turkish Journal of Zoology, 39, 210-224. https://doi.org/10.3906/zoo-1307-35.

McGeer, J. C., Brix, K. V., Skeaff, J. M., DeForest, D. K., Brigham, S. I., Adams, W. J., \& Green, A. (2003). Inverse relationship between bioconcentration factor and exposure concentration for metals: implications for hazard assessment of metals in the aquatic environment. Environmental Toxicology and Chemistry, 22, 1017-1037. https://doi. org/10.1002/etc.5620220509.

McMeans, B. C., Svavarsson, J., Dennard, S., \& Fisk, A. T. (2010). Diet and resource use among Greenland sharks (Somniosus microcephalus) and teleosts sampled in Icelandic waters, using delta C-13, delta N-15, and mercury. Canadian Journal of Fisheries and Aquatic Sciences, 67, 1428-1438. https://doi.org/10.1139/F10-072.

Molina, C. I., Gibon, F. M., Duprey, J. L., Dominguez, E., Guimaraes, J. R. D., \& Roulet, M. (2010). Transfer of mercury and methylmercury along macroinvertebrate food 
chains in a floodplain lake of the Beni River, Bolivian Amazonia. Sci Total Environ, 408, 3382-3391. https://doi. org/10.1016/j.scitotenv.2010.04.019.

Morawski, M. (1978). Biology and ecology of Gobius niger L. and Pomatoschistus minutus (Pallas) (Gobiidae) from the Gulf of Gdańsk. Gdańsk: PhD Thesis, University of Gdańsk (in Polish).

Napiórkowska-Krzebietke, A. (2009). Diversity and dynamics of phytoplankton in lakes Licheńskie and Ślesińskie in 20042005. Archives of Polish Fisheries, 17, 253-265. https://doi. org/10.2478/v10086-009-0018-8.

Newman, M. C., Xu, X. Y., Cotton, C. F., \& Tom, K. R. (2011). High mercury concentrations reflect trophic ecology of three deep-water chondrichthyans. Archives of Environmental Contamination and Toxicology, 60, 618-625. https://doi. org/10.1007/s00244-010-9584-4.

Nfon, E., Cousins, I. T., \& Broman, D. (2008). Biomagnification of organic pollutants in benthic and pelagic marine food chains from the Baltic Sea. Science of the Total Environment, 397, 190-204. https://doi.org/10.1016/j. scitotenv.2008.02.029.

Nordstöm, M., Aarnio, K., \& Bonsdorff, E. (2009). Temporal variability of a benthic food web: patterns and processes in a low-diversity system. Marine Ecology Progress Series, 378, 13-26. https://doi.org/10.3354/meps07872.

Olenin, S., \& Daunys, S. (2005). Invaders in suspension-feeder systems: variations along the regional environmental gradient and similarities between large basins. In R. Dame \& S. Olenin (Eds.), The comparative roles of suspension-feeders in ecosystems. NATO Science Series (Vol. 47, pp. 221-237). Dordrecht: Springer. https://doi.org/10.1007/1-4020-3030-4.

Olivier, M., Desrosiers, G., Caron, A., Retière, C., \& Caillou, A. (1995). Réponses comportementales des polychètes Nereis diversicolor (O.F. Müller) et Nereis virens (Sars) aux stimuli d'ordre alimentaire: utilisation de la matière organique particulaire (algues et halophytes). Canadian Journal of Zoology, 73, 2307-2317. https://doi.org/10.1139/z95-273 (in French).

Olsen, Y. S., Fox, S. E., Teichberg, M., Otter, M., \& Valiela, I. (2011). $\delta^{15} \mathrm{~N}$ and $\delta^{13} \mathrm{C}$ reveal differences in carbon flow through estuarine benthic food webs in response to the relative availability of macroalgae and eelgrass. Marine Ecology Progress Series, 421, 83-96. https://doi.org/10.3354 /meps08900.

Pekcan-Hekim, Z., Liljendahl-Nurminen, A., \& Horppila, J. (2006). Chaoborus flavicans in the food web-competitor or resource for fish? Polish Journal of Ecology, 54, 701-707.

Pethybridge, H., Butler, E. C. V., Cossa, D., Daley, R., \& Boudou, A. (2012). Trophic structure and biomagnification of mercury in an assemblage of deepwater chondrichthyans from Southeastern Australia. Marine Ecology Progress Series, 45, 163-174. https://doi.org/10.3354/meps09593.

Pickhardt, P. C., Folt, C. L., Chen, C. Y., Klaue, B., \& Blum, J. D. (2002). Algal blooms reduce the uptake of toxic methylmercury in freshwater food webs. PNAS, 99, 4419-4423. https://doi.org/10.1073/pnas.072531099.

Prado, P., Vergara, C., \& Ibáñez, C. (2013). Influence of salinity regime on the food-web structure and feeding ecology of fish species from Mediterranean coastal lagoons. Estuarine, Coastal and Shelf Science, 139, 1-10. https://doi. org/10.1016/j.ecss.2013.12.013.
Reusch, T. B. H., Dierking, J., Andersson, H. C., Bonsdroff, E., Carstensen, J., Casini, M., Czajkowski, M., Hasler, B., Hinsby, K., Hyytiäinen, K., Johannesson, K., Jomaa, S., Jormalainen, V., Kuosa, H., Kurland, S., Laikre, L., MacKenzie, B. R., Margoński, P., Melzner, F., Oesterwind, D., Ojaveer, H., Refsgaard, J. C., Sandström, A., Schwarz, G., Tonderski, K., Winder, M., \& Zandersen, M. (2018). The Baltic Sea as a time machine for the future coastal ocean. Science Advances, 4, eaar8195. https://doi.org/10.1126 /sciadv.aar8195.

Riera, P. (2010). Trophic plasticity of the gastropod Hydrobia ulvae within an intertidal bay (Roscoff, France): a stable isotope evidence. Journal of Sea Research, 63, 78-83. https://doi.org/10.1016/j.seares.2009.10.001.

Riera, P., Stal, L. J., Nieuwenhuize, J., Richard, P., Blanchard, G. F., \& Gentil, F. (1999). Determination of food sources for benthic invertebrates in a salt marsh (Aiguillon Bay, France) by carbon and nitrogen stable isotopes: importance of locally produced sources. Marine Ecology Progress Series, 187, 301-307. https://doi.org/10.3354/meps187301.

Rigét, F., Møller, P., Dietz, R., Nielsen, T. G., Asmund, G., Strand, J., Larsen, M. M., \& Hobson, K. A. (2007). Transfer of mercury in the marine food web of West Greenland. Journal of Environmental Monitoring, 9, 877-883. https://doi.org/10.1039/B704796G.

Riisgård, H. U., \& Schotge, P. (2007). Surface deposit feeding versus filter feeding in the amphipod Corophium volutator. Marine Biology Research, 3, 421-427. https://doi. org/10.1080/17451000701696302.

Riyadi, A. S., Itai, T., Hayase, D., Isobe, T., Horai, S., Miller, T. W., Omori, K., Sadryanto, A., Ilyas, M., Setiawan, I. E., \& Tanabe, S. (2015). Mercury in temperate and tropical regions case studies on the Oregon Coast, USA, Sanriku Coast, Japan, and Jakarta Bay, Indonesia. Chemistry Letters, 44, 1470-1472. https://doi.org/10.1246/cl.150579.

Rodrigues, P., \& Reynoldson, T. B. (2011). The pollution biology of aquatic oligochaetes (p. 265). Dordrecht: Springer. https://doi.org/10.1007/978-94-007-1718-3.

Rolff, C., Broman, D., Näf, C., \& Zebühr, Y. (1993). Potential biomagnification of $\mathrm{PCDD} / \mathrm{Fs}$ - new possibilities for quantitative assessment using stable isotope trophic position. Chemosphere, 27, 461-468. https://doi.org/10.1016/00456535(93)90327-2.

Rossi, F., Herman, P. M. J., \& Middelburg. (2004). Interspecific and intraspecific variation of $\delta \mathrm{C}$ and $\delta \mathrm{N}$ in deposit- and suspension-feeding bivalves (Macoma balthica and Cerastoderma edule): evidence of ontogenetic changes in feeding mode of Macoma balthica. Limnology and Oceanography, 49, 408-414. https://doi.org/10.4319 /lo.2004.49.2.0408.

Sanseverino, A. M., \& Nessimian, J. L. (2001). Habitats of chironomid larvae (Insecta, Diptera) in streams of the Atlantic Forest in Rio de Janeiro State. Acta Limnologica Brasiliensia, 13, 29-38.

Santisteban, J. I., Mediavilla, R., Lopez-Pamo, E., Dabrio, C. J., Zapata, M. B. R., Garci, M. J. G., Castano, S., \& MartınezAlfaro, P. (2004). Loss on ignition: a qualitative or quantitative method for organic matter and carbonate mineral content in sediments? Journal of Paleolimnology, 32, 287-299. https://doi.org/10.1023/B:JOPL.0000042999.30131.5b. 
Seeberg-Elverfeldt, J., Schlüter, M., Feseker, T., \& Kölling, M. (2005). Rhizon sampling of porewaters near the sedimentwater interface of aquatic systems. Limnology and Oceanography: Methods, 3, 361-371. https://doi. org/10.4319/lom.2005.3.361.

Sokołowski, A. (2009). Tracing the flow of organic matter based upon dual stable isotope technique, and trophic transfer of trace metals in benthic food web of the Gulf of Gdan'sk (southern Baltic Sea) (p. 213). Gdańsk: University of Gdańsk Press.

Sokołowski, A., Wołowicz, M., Asmus, H., Asmus, R., Carlier, A., Gasiunaité, Z., Grémare, A., Hummel, H., Lesutiené, J., Razinkovas, A., Renaud, P. E., Richard, P., \& Kędra, M. (2012). Is benthic food web structure related to diversity of marine microbenthic communities? Estuarine, Coastal and Shelf Science, 108, 76-86. https://doi.org/10.1016/j. ecss.2011.11.011.

Sokołowski, A., Ziółkowska, M., \& Zgrundo, A. (2015). Habitatrelated patterns of soft-bottom macrofaunal assemblages in a brackish, low-diversity system (southern Baltic Sea). Journal of Sea Research, 103, 93-102. https://doi.org/10.1016/j. seares.2015.06.017.

Szefer, P., Ali, A. A., Ba-Haroon, A. A., Rajeh, A. A., Geldon, L., \& Nabrzyski, M. (1999). Distribution and relationships of selected trace metals in molluscs and associated sediments from the Gulf of Aden, Yemen. Environmental Pollution, 106, 299-314. https://doi.org/10.1016/S0269-7491(99 )00108-6.

Szymelfenig, M. (2008). Współcześni mieszkańcy Bałtyku. In M. Szymelfenig \& J. Urbański (Eds.), Morze Baltyckie - o tym warto wiedzieć (pp. 38-83). Polski Klub Ekologiczny: Gdańsk (in Polish).

Tischler, W. (1949). Grundzüge der terrestrischen Tierökologie (p. 219). Vieweg Teubner Verlag: Braunschweig. https://doi. org/10.1007/978-3-663-02549-8 (in German).
Törnroos, A., \& Bonsdorff, E. (2012). Developing the multitrait concept for functional diversity: lessons from a system rich in functions but poor in species. Ecological Applications, 22, 2221-2236. https://doi.org/10.1890/11-2042.1.

Trojan, P. (1980). Ekologia ogólna (p. 419). Warszawa: PWN (in Polish).

Tukey, J. W. (1997). Exploratory data analysis (p. 688). Reading: Addison-Wesley.

van de Bund, W. J., Goedkoop, W., \& Johnson, R. K. (1994). Effects of deposit-feeder activity on bacterial production and abundance in profundal lake sediment. Journal of the North American Benthological Society, 13, 532-539. https://doi. org/10.2307/1467849.

Warzocha, J. (2009). Polish marine areas: Zoobenthos. In: Atlas of Polish marine area bottom habitats (pp. 60-83). Gdynia: Broker Innowacji.

Węsławski, J. M., Kryla-Straszewska, L., Piwowarczyk, J., Urbański, J., Warzocha, J., Kotwicki, L., WłodarskaKowalczuk, M., \& Wiktor, J. (2013). Habitat modelling limitations-Puck Bay, Baltic Sea-a case study. Oceanologia, 55, 167-183. https://doi.org/10.5697/oc.551.167.

Wrembel, H. Z. (1993). Atmosphere and rivers as the major sources of mercury to the Baltic Sea (p. 143). Słupsk: Słupsk Pomeranian University.

Wyn, B., Kidd, K. A., Burgess, N. M., \& Curry, R. A. (2009). Mercury biomagnification in the food webs of acidic lakes in Kejimkujik National Park and National Historic Site, Nova Scotia. Canadian Journal of Fisheries and Aquatic Sciences, 66, 1532-1545. https://doi.org/10.1139/F09-097.

Zhao, L., Yang, F., \& Yan, X. (2013). Biomagnification of trace elements in a benthic food web: the case study of Deer Island (Northern Yellow Sea). Chemistry and Ecology, 29, 197207. https://doi.org/10.1080/02757540.2012.753062.

Żmudziński, L. (1990). Świat zwierzęcy Battyku. Atlas makrofauny (p. 196). Warszawa: PWN (in Polish). 